\title{
Brain Cytochrome Oxidase: Purification, Antibody Production, and Immunohistochemical/Histochemical Correlations in the CNS
}

\author{
Robert F. Hevner and Margaret T. T. Wong-Riley \\ Department of Anatomy and Cellular Biology, Medical College of Wisconsin, Milwaukee, Wisconsin 53226
}

Cytochrome oxidase (CO) is a mitochondrial energy-generating enzyme used in brain studies as a marker of neural functional activity. The activity of $\mathrm{CO}$ in different brain regions, revealed histochemically, is distributed nonhomogeneously but in distinct patterns. Localized differences in $\mathrm{CO}$ activity could arise from localized differences in enzyme amount or from localized regulation of enzyme turnover number (molecular activity). To distinguish between these alternatives, we used antibodies against purified calf brain $\mathrm{CO}$ to assess the immunohistochemical distribution of $\mathrm{CO}$ amount (protein immunoreactivity) in several brain regions.

Calf brain mitochondria (synaptic and nonsynaptic populations) were isolated from gray matter homogenates by differential centrifugation. CO was purified from detergent extracts of the mitochondria by cytochrome c-Sepharose $4 \mathrm{~B}$ affinity chromatography. Antisera against the purified $\mathrm{CO}$ were raised in rabbits. The antibodies reacted specifically with $\mathrm{CO}$, predominantly subunit IV, in SDS immunoblots. The antibodies did not react in SDS immunoblots with any other proteins solubilized from mitochondria or caudate nucleus but did cross-react with brain $\mathrm{CO}$ from other mammalian species and with bovine heart $C O$.

The immunohistochemical distribution of $\mathrm{CO}$ amount matched the histochemical distribution of $\mathrm{CO}$ activity in all regions tested, including the monkey hippocampus and the mouse olfactory bulb, somatosensory (barrel) cortex, and cerebellum. Thus, the amount of $\mathrm{CO}$ in neural tissue is distributed in the same nonhomogeneous pattern as the histochemical activity of $\mathrm{CO}$. The results suggest that mechanisms exist by which $\mathrm{CO}$ molecules are selectively distributed within neurons to meet local metabolic demands posed by neural functional activity.

Neural functional activity is an energy-requiring process. Thus, the local rate of energy metabolism and the local level of functional activity are tightly coupled in the nervous system (Krnjevic, 1975; Sokoloff, 1984). This principle has been thoroughly demonstrated using the 2-deoxyglucose (2-DG) technique, in which the relative uptake of radiolabeled 2-DG (a glucose an-

\footnotetext{
Received Mar. 3, 1989; revised Apr. 21, 1989; accepted Apr. 26, 1989.

This work was supported by NIH grants NS18122 and EY05439 (M.W.R.) and by the Medical Scientist Training Program at the Medical College of Wisconsin (R.F.H.). We thank Dr. Ed Krug for practical advice on our biochemical experiments, Dr. V. M. Haughton and Dr. C. Nguyen-minh for generously providing monkey brain tissue, Dr. A. Haas for critically reading the manuscript, and $\mathrm{X}$. Luo, W. Kaboord, and S. Liu for assistance in the laboratory.

Correspondence should be addressed to Dr. Margaret T. T. Wong-Riley, Department of Anatomy and Cellular Biology, Medical College of Wisconsin, 8701 Watertown Plank Rd., Milwaukee, WI 53226.

Copyright (C) 1989 Society for Neuroscience $0270-6474 / 89 / 113884-15 \$ 02.00 / 0$
}

alog) among brain regions is determined autoradiographically and correlated with the conditions of functional activity imposed during 2-DG administration (Sokoloff, 1984). Using this technique, it has been shown, for example, that when one eye is visually stimulated in primates, the rate of energy metabolism is higher in cortical ocular dominance columns corresponding to the stimulated versus the nonstimulated eye (Kennedy et al., 1976).

Not only is the rate of energy metabolism coupled to functional activity, but so also is the capacity for generating metabolic energy. The relative capacity for energy metabolism among brain regions is demonstrated using cytochrome oxidase histochemistry. Cytochrome oxidase (CO; ferrocytochrome $c$ /oxygen oxidoreductase, EC 1.9.3.1; for review, see Kadenbach et al., 1987) is the terminal complex of the mitochondrial respiratory chain, which generates ATP by oxidative phosphorylation. In $\mathrm{CO}$ histochemistry, the relative distribution of $\mathrm{CO}$ activity is visualized in tissue sections. The relative $\mathrm{CO}$ activity is an indicator of local tissue metabolic capacity, which is coupled to neural functional activity (reviewed by Wong-Riley, 1989).

In normal neural tissue, the capacity for energy metabolism, as revealed by $\mathrm{CO}$ histochemistry, varies so that different local tissue regions have different metabolic capacities. This variation occurs at the regional, laminar, cellular, and subcellular levels. This suggests that neural functional activity also varies locally, since $\mathrm{CO}$ activity is coupled to functional activity.

The local variations in $\mathrm{CO}$ activity are not random but follow a clear and reproducible pattern in a given brain region. For example, in the primate visual cortex, $\mathrm{CO}$ activity is highest in lamina $4 \mathrm{C}$ and forms a periodic pattern of puffs (also called patches or blobs) in laminae 2 and 3 (Horton and Hubel, 1981; Carroll and Wong-Riley, 1984; Horton, 1984). Physiological (Livingstone and Hubel, 1984) and 2-DG (Hendrickson and Wilson, 1979; Tootell et al., 1988) studies suggest that these regions of high $\mathrm{CO}$ activity are also regions of high functional activity. In the visual cortex and in other brain regions as well, the normal distribution of $\mathrm{CO}$ activity seems to reflect the coupling between energy metabolic capacity and neural functional activity (Wong-Riley, 1989).

The biochemical mechanisms linking functional activity and energy metabolic capacity somehow cause $\mathrm{CO}$ activity levels to vary locally within neural tissue. Regions of high $\mathrm{CO}$ total activity in brain tissue could contain larger amounts of $\mathrm{CO}$ protein, or the amount of $\mathrm{CO}$ might be the same, with individual enzyme molecules having a higher turnover number (molecular activity). The total activity of $\mathrm{CO}$ equals the product of these two factors (amount and turnover number). Many metabolic enzymes are known to be regulated at the level of amount (Schimke and 
Doyle, 1970), whereas others are known to be regulated at the level of turnover number by such mechanisms as covalent modification (Cohen, 1980a, b).

The goal of this study was to distinguish whether mainly the amount or mainly the turnover number of $\mathrm{CO}$ is locally regulated in neural tissue. To determine the relative distribution of $\mathrm{CO}$ amount, antibodies against purified $\mathrm{CO}$ were generated and used to label $\mathrm{CO}$ immunohistochemically in brain tissue sections. The $\mathrm{CO}$ immunohistochemical pattern in each region was then compared with the $C O$ histochemical pattern. Several brain regions known to have unique and characteristic patterns of $\mathrm{CO}$ activity were examined; these were the monkey hippocampus, and the mouse olfactory bulb, somatosensory (barrel) cortex, and cerebellum.

In each region tested, the $\mathrm{CO}$ immunohistochemical pattern matched the $\mathrm{CO}$ histochemical pattern. We conclude that $\mathrm{CO}$ molecules are distributed nonhomogeneously in neural tissue in a pattern that could account for the distribution of $\mathrm{CO}$ activity without postulating a major role for regulation of $\mathrm{CO}$ turnover number. A preliminary report of this work has appeared in abstract form (Hevner and Wong-Riley, 1987).

\section{Materials and Methods}

General chemicals. Triton X-100, Triton X-114 (both polymers of polyoxyethylene p-t-octyl phenol), and Tween 20 (polyoxyethylene sorbitan monolaurate) were purchased from Sigma. Concentrations of these detergents are expressed as percentage (vol/vol). Horse heart (type III) and yeast (type VIII-B) cytochrome $c$ also were from Sigma.

Isolation of mitochondria. Synaptic and nonsynaptic mitochondria were prepared from calf brain by the differential centrifugation procedure of Rendon and Masmoudi (1985), modified to accommodate a larger mass of tissue. For each preparation, 1 calf (16-17-week-old Holstein bull) brain was obtained fresh, packed in ice, and homogenized (Potter-Elvehjem type homogenizer) within 45 min postmortem. In order to minimize myelin contamination of the homogenate, only the cerebral cortex (scraped from the brain surface) and caudate nuclei were used as starting material. Their combined mass was usually $\sim 120-150$ gm.

Modifications to the procedure of Rendon and Masmoudi (1985) were made as follows. (1) After the first centrifugation step, the nuclear pellet was washed once to increase the recovery of mitochondria, since about one third of the $\mathrm{CO}$ activity was found in the first nuclear pellet. (2) The washed P2 pellet was resuspended in 120 or $180 \mathrm{ml}$ of isolation buffer rather than $30 \mathrm{ml}$. (3) The washed synaptosomal fraction was lysed in $200 \mathrm{ml}$ of hypotonic buffer rather then $40 \mathrm{ml}$.

Solubilization of $C O$ from isolated mitochondria. Cytochrome $c$-depleted mitochondria were prepared from isolated mitochondria (50$150 \mathrm{mg}$ protein) by the method of Jacobs and Sanadi (1960). Partially purified, solubilized $\mathrm{CO}$ was prepared from the cytochrome $c$-depleted mitochondria by the method of Jacobs et al. (1966a, b). The following modifications were made: (1) a higher concentration of Triton X-114 $(0.006 \mathrm{ml} 20 \%$ Triton X-1 14/mg protein) was used in the initial detergent extraction (this improved the subsequent $\mathrm{CO}$ purity and stability to desalting), and (2) the $K$ phosphate $\left(P_{i}\right)$ concentration was increased to $0.5 \mathrm{M}$ in the solubilization with Triton X-100 (this improved solubility and stability).

Solubilization of commercially obtained bovine heart $\mathrm{CO}$. Bovine heart

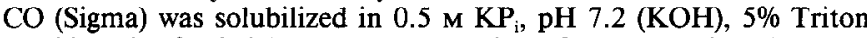
$\mathrm{X}-100$ on ice for $2-8 \mathrm{hr}$, at a concentration of $4 \mathrm{mg}$ protein $/ \mathrm{ml}$. Lower salt or detergent concentrations failed to solubilize the enzyme, and higher detergent concentrations led to loss of enzyme activity. Insoluble material was removed by centrifugation at $105,000 \mathrm{~g}(\max )$ for $60 \mathrm{~min}$ at $4^{\circ} \mathrm{C}$. More than $95 \%$ of the $\mathrm{CO}$ activity remained in the supernatant. The specific heme a content of the enzyme obtained from Sigma was $1.0 \mathrm{nmol}$ heme $\mathrm{a} / \mathrm{mg}$ protein.

Purification of $\mathrm{CO}$. All procedures were at $0-4^{\circ} \mathrm{C}$. Solubilized crude heart or brain CO (5-15 mg protein) was desalted on a Sephadex G-100 (Pharmacia) column pre-equilibrated with $40 \mathrm{~mm}$ HEPES, $\mathrm{pH} 7.4$ $\left(\mathrm{KOH}, \mathrm{pH} 7.6\right.$ at $\left.4^{\circ} \mathrm{C}\right), 0.05 \%$ Triton X-100. Fractions with CO activity were pooled and applied to a $1.5 \times 3.7 \mathrm{~cm}$ column of yeast cytochrome
c-Sepharose 4B (prepared by the method of Broger et al., 1986). The affinity column was pre-equilibrated with $40 \mathrm{~mm}$ HEPES, $\mathrm{pH} 7.4,0.05 \%$ Triton X-100. The sample (5-10 mg protein) was applied to the column and washed with pre-equilibration buffer until the A280 nm and A405 $\mathrm{nm}$ (monitored with an ISCO Type 6 Optical Unit, UA-5 Absorbance Detector, and Model 1133 Multiplexer/Expander) returned to baseline. The column was further washed with 5-10 column volumes of $40 \mathrm{~mm}$ HEPES, pH 7.4, 0.5\% Triton X-100, then eluted with $25 \mathrm{ml}$ (total) of this buffer containing a linear gradient of $0-100 \mathrm{mM} \mathrm{KP}_{\mathrm{i}}, \mathrm{pH} 7.4(\mathrm{KOH})$. The column flow rate was $2.1 \mathrm{~cm} / \mathrm{hr}$ during the loading and elution steps and $4.3 \mathrm{~cm} / \mathrm{hr}$ during the wash. Fractions $(2 \mathrm{ml})$ were assayed for $\mathrm{CO}$ activity, cytochromes, conductivity (to estimate $\mathrm{KP}$ ), and protein.

Biochemical assays. Protein concentrations were determined spectrophotometrically in triplicate by the modified Bradford (1976) method of Read and Northcote (1981; dye-reagent no. 2) or by the BCA method (Pierce). The standard was BSA (Sigma).

$\mathrm{CO}$ activity was determined spectrophotometrically in triplicate at $30^{\circ} \mathrm{C}$ by the procedure of Wharton and Tzagoloff (1967), using the buffer system of Errede et al. (1978). The relation between cytochrome $c$ oxidized versus cytochrome $a a_{3}$ added to the reaction was linear under these conditions. Activity was expressed as units, where $1 \mathrm{unit}=1 \mu \mathrm{mol}$ cytochrome $c$ oxidized $/ \mathrm{min}$. The assay conditions are approximately saturating for $\mathrm{CO}$, so no further kinetic analyses were performed in estimating turnover numbers (molecular activity).

Cytochromes were assayed spectrophotometrically by the procedure of Vanneste (1966). Mitochondrial suspensions were solubilized in an equal volume of ice-cold $0.5 \mathrm{M} \mathrm{KP}$, pH $7.4(\mathrm{KOH}), 5 \%$ Triton X-100. A minimum of 2 volumes of PBS ( $140 \mathrm{~mm} \mathrm{NaCl}, 2.7 \mathrm{~mm} \mathrm{KCl}, 1.5 \mathrm{~mm}$ $\mathrm{KP}_{\mathrm{i}}, 8.1 \mathrm{mM} \mathrm{Na}_{2} \mathrm{P}_{\mathrm{i}}, \mathrm{pH} 7.4$ ) containing $4 \%$ Triton $\mathrm{X}-100$ was then added to the mitochondria to ensure complete solubilization. The spectrophotometer chamber was cooled to $5^{\circ} \mathrm{C}$ to prevent aggregation, which occurred if the mitochondrial solution warmed.

Electrophoresis. Chemicals for electrophoresis were purchased from Bio-Rad or Research Organics. Urea-SDS-PAGE was by the procedure of Kadenbach et al. (1983), using a Bio-Rad Protean II apparatus and $1.5 \mathrm{~mm}$ thick gels. Gels were stained with $0.05 \%$ Serva blue R in $25 \%$ isopropanol, $10 \%$ acetic acid, or by the silver staining procedure of Wray et al. (1981) with glutaraldehyde $(0.0125 \%$ in $50 \%$ methanol) enhancement (Dion and Pomenti, 1983). Molecular weight standards were purchased from Bio-Rad, BRL, or Amersham (prestained Rainbow standards). Subunits were identified using the nomenclature of Kadenbach et al. (1983).

Animal brain tissue samples were solubilized for electrophoretic and immunoblot analysis in $10 \%(\mathrm{wt} / \mathrm{vol})$ SDS, at a ratio of $1 \mathrm{mg}$ wet tissue/ $5 \mu 110 \%$ SDS, then further diluted into electrophoresis sample buffer. Brain tissue was assumed to contain $10 \%$ protein by weight (wet).

Immunoblotting. Proteins were transferred electrophoretically from polyacrylamide gels to nitrocellulose (Schleicher and Schuell type BA-83) by the procedure of Towbin et al. (1979) as modified by KuhnNentwig and Kadenbach (1985), using a Bio-Rad Trans-Blot Cell. KuhnNentwig and Kadenbach (1985) found that all CO subunits were transferred under their conditions. We did not assess transfer of $\mathrm{CO}$ subunits in our experiments but did observe that all molecular weight markers (as low as $6.2 \mathrm{kDa}$ ) were transferred. For immunolabeling, blots were blocked overnight at $4^{\circ} \mathrm{C}$ with $5 \%$ (wt/vol) nonfat dry milk in PBS (PBSNFDM; Johnson et al., 1984). PBS-NFDM was also used for washes betwecn antibody incubations and for antibody dilution. The blocked blot was incubated overnight at $4^{\circ} \mathrm{C}$ with primary antibody (anti-CO or preimmune serum at 1:2000), washed, then incubated with secondary antibody (Bio-Rad blotting grade goat anti-rabbit IgG, HRP conjugate, GaR-HRP, 1:2000) for 2-4 hr at room temperature. The blot was finally washed in PBS containing 0.2\% Tween 20 (PBS-Tween) and developed for $5-15 \mathrm{~min}$ at room temperature with $0.01 \mathrm{mg} / \mathrm{ml} \mathrm{4-chloro-} \alpha$ naphthol, $0.01 \%$ (wt/vol) $\mathrm{H}_{2} \mathrm{O}_{2}$, in $1: 5$ methanol : PBS.

ELISA assays. All antibody titers were determined by ELISA. The titer was defined as the maximal dilution (lowest concentration) of antiserum in which antibodies were detected. All ELISA incubations were at $4^{\circ} \mathrm{C}$ on a rotator. PBS-NFDM was used for washes between incubations (except where noted) and for dilutions of antibodies. Washes between incubations were done 3 times for $5 \mathrm{~min}$. Controls (no primary antibody, preimmune serum) were run with every assay platc.

Polystyrene flat-bottom wells (Dynatech Immulon II) were coated overnight with $100 \mu \mathrm{l} /$ well purified $\mathrm{CO}(8.4 \mathrm{nmol} \mathrm{heme} \mathrm{a} / \mathrm{mg}$ protein) at $1 \mu \mathrm{g} / \mathrm{ml}$ in $0.1 \mathrm{M} \mathrm{NaHCO}_{3}, \mathrm{pH} 9.0$. After coating with $\mathrm{CO}$, the wells were blocked for $8 \mathrm{hr}$ with $200 \mu \mathrm{l}$ PBS-NFDM. The wells were washed 
and incubated with primary antibody ( $100 \mu 1 /$ well, serial dilutions) for $8-12 \mathrm{hr}$. The wells were washed again and incubated with $100 \mu \mathrm{l} /$ well secondary antibody (Bio-Rad blotting grade GaR-HRP, 1:1000) for 8$12 \mathrm{hr}$. After a final wash with PBS-Tween, the assay was developed with $100 \mu \mathrm{l} /$ well $3.8 \mathrm{~mm} 2,2$ '-azinobis (3-ethylbenzothiazoline-6-sulfonic acid),

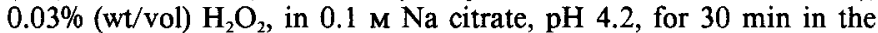
dark. The reaction was stopped by the addition of $25 \mu \mathrm{l} /$ well $10 \%$ (wt/ vol) SDS. The A650 nm in each well was read on a Bio-Tek EL309 Microplate Autoreader.

Antibody production. Two female New Zealand White rabbits were immunized by the method of Hurn and Chantler (1980). One rabbit was selected for continued use of its antiserum based on its high antibody titer. This animal received a primary dose of $100 \mu \mathrm{g}$ purified $(9.9 \mathrm{nmol}$ heme $\mathrm{a} / \mathrm{mg}$ protein) bovine brain $\mathrm{CO}$ emulsified with complete Freund's adjuvant (Difco) and injected at multiple intradermal and subcutaneous sites on the animal's back. The booster dose, containing $200 \mu \mathrm{g}$ purified brain $\mathrm{CO}(9.9 \mathrm{nmol}$ heme a/mg protein) emulsified with complete Freund's adjuvant, was injected 10 weeks later at intramuscular sites in all four limbs. (The other animal was immunized by identical procedures but received primary and booster doses of $100 \mu \mathrm{g}$ and $50 \mu \mathrm{g}$ $\mathrm{CO}$, respectively.) The rabbits were killed by sodium pentobarbital overdose.

IgG was purified from serum by DEAE-Affi Gel Blue chromatography (Bio-Rad) according to the manufacturer's instructions. IgG preparations were always used in $\mathrm{CO}$ immunohistochemistry, since background staining was lower. The anti-CO titer in IgG preparations was 20 -fold less than that in sera because of dilution during chromatography. All anti-CO dilutions were normalized to the appropriate dilution of serum; e.g., IgG at 1:100 dilution was equivalent to serum at 1:2000 dilution. Serum and IgG preparations were stored frozen at $-20^{\circ} \mathrm{C}$ or $-70^{\circ} \mathrm{C}$ or lyophilized and frozen. Freezing and lyophilization did not affect antiCO titers.

Indirect immunoprecipitation. Protein A-Sepharose CL-4B (Pharmacia; $\sim 2 \mathrm{mg}$ protein $\mathrm{A} / \mathrm{ml}$ swollen gel) was hydrated in PBS and washed with PBS containing $1 \%$ Triton X-100. Serum (5-60 $\mu$ l of preimmune or anti-CO) was mixed in polypropylene microcentrifuge tubes with washed protein A-Sepharose CL-4B (20-70 $\mu$ l) and brought to a total volume of $192 \mu \mathrm{l}$ with PBS. The molar ratio of protein A IgGbinding sites/IgG in each tube was adjusted to $>2$, based on a protein A molecular mass of $42 \mathrm{kDa}$, and two IgG-binding sites per protein $\mathrm{A}$ (Surolia et al., 1982); and an IgG molecular mass of $\sim 150 \mathrm{kDa}$ and concentration in serum of $\sim 10 \mathrm{mg} / \mathrm{ml}$ (Johnstone and Thorpe, 1982). Tubes containing protein A-Sepharose and serum were incubated on a rotator for $45 \mathrm{~min}$ at room temperature, then cooled on ice. To each tube, $8 \mu \mathrm{l}$ of solubilized crude heart or brain $\mathrm{CO}$ was added. The tubes were incubated for $60 \mathrm{~min}$ at $4^{\circ} \mathrm{C}$ on a rotator, centrifuged for $\sim 5 \mathrm{sec}$ to pellet the Sepharose beads, and assayed for $\mathrm{CO}$ activity in the supernatant.

Preabsorption of anti-CO. Antibodies reactive with purified $\mathrm{CO}$ were solid-phase absorbed by affinity chromatography against $\mathrm{CO}-$ Sepharose 4B, followed by incubation with CO absorbed to ELISA plates.

In the affinity chromatography step, purified $(9.7 \mathrm{nmol}$ heme $\mathrm{a} / \mathrm{mg}$ protein) calf brain $\mathrm{CO}(466 \mu \mathrm{g})$ was coupled to $133 \mu \mathrm{l}$ swollen $\mathrm{CNBr}-$ activated Sepharose 4B (Pharmacia) according to the manufacturer's instructions, except that $0.1 \%$ Triton $\mathrm{X}-100$ was added to all solutions. The coupling reaction was successful, since the green $\mathrm{CO}$ color remained with the beads. The CO-Sepharose beads were poured into a pipette tip to make a column of volume $90 \mu \mathrm{l}$. The column was equilibrated at $4^{\circ} \mathrm{C}$ with PBS, $0.1 \%$ Triton $X-100$. Lyophilized anti-CO was dissolved in PBS, $0.1 \%$ Triton X-100, at a relative dilution of $1: 20$ and passed over the column at $200 \mu \mathrm{l} / \mathrm{hr}$. Fractions $(67 \mu \mathrm{l})$ were collected and tested for anti-CO by ELISA. Residual anti-CO was detected, so a second absorption step was used.

In the second step, polystyrene wells were coated with purified $\mathrm{CO}$ and blocked with PBS-NFDM as described for ELISA assays. Partially absorbed anti-CO from the first step was diluted with PBS-NFDM to a final relative concentration of $1: 400$ and incubated with the $\mathrm{CO}$-coated wells $\left(100 \mu \mathrm{l} /\right.$ well) for $8 \mathrm{hr}$ at $4^{\circ} \mathrm{C}$. The absorbed anti-CO was recovered with a micropipette and used in immunohistochemical control experiments.

Animal tissue preparation. Six adult mice (4 BALB/c and 2 C57Bl) and 2 adult female bonnet macaque monkeys (2-3 $\mathrm{kg}$ Macaca radiata) were used for histologic studies. The monkeys received intraocular injections of TTX into the left eye as part of another study. The mice were killed by cervical dislocation. The monkeys were deeply anesthe- tized (sodium pentobarbital, $65 \mathrm{mg} / \mathrm{kg}$ ) and decapitated. Tissues were removed from the animals and fixed by immersion in $4 \%$ paraformal-

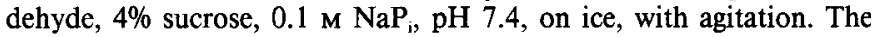
tissue was kept at $4^{\circ} \mathrm{C}$ in all further work until sectioning. After fixation for 4-6 hr, the tissues were rinsed in $4 \%$ sucrose, $0.1 \mathrm{M} \mathrm{NaP}{ }_{\mathrm{i}}$ buffer, $\mathrm{pH}$ 7.4 , then equilibrated with buffer containing increasing sucrose concentrations $(10 \%, 20 \%, 30 \%)$ as a cryoprotectant to prevent freezing artifact. Sections were cut at $15-30 \mu \mathrm{m}$ on a freezing microtome and placed in PBS on ice until further processed. Alternate sections of all tissues were designated for $\mathrm{CO}$ histochemistry and immunohistochemistry. Occasional sections were used for Nissl ( $1 \%$ cresyl violet) staining.

CO histochemistry. Sections were processed for CO histochemistry by the method of Wong-Riley (1979).

CO immunohistochemistry. Free-floating sections were blocked for $8-24 \mathrm{hr}$ at $4^{\circ} \mathrm{C}$ in PBS-NFDM containing $1 \%$ Triton X-100 and $1-5 \%$ ( $\mathrm{vol} / \mathrm{vol}$ ) normal goat serum (NGS). The sections were rinsed in PBS, then incubated in primary antibody (anti-CO at 1:2000-8000) or preimmune serum (at 1:2000-5000) diluted in PBS-NFDM with $1 \%$ Triton $\mathrm{X}-100$ and $5 \% \mathrm{NGS}$, for $4 \mathrm{hr}$ at room temperature, then for $8-24 \mathrm{hr}$ at $4^{\circ} \mathrm{C}$. The sections were rinsed, then incubated with secondary antibody (Bio-Rad blotting grade GaR-HRP or Boehringer Mannheim goat antirabbit IgG, fluorescein conjugate) at 1:100 in PBS-NFDM with 5\% NGS for $6 \mathrm{hr}$ at room temperature or overnight at $4^{\circ} \mathrm{C}$. The sections were again rinsed. Sections for immunofluorescence were incubated in tertiary antibody (Boehringer Mannheim swine anti-goat IgG, fluorescein conjugate, 1:100 in PBS-NFDM with 5\% NGS) for 8-12 hr at $4^{\circ} \mathrm{C}$, rinsed, mounted in 9:1 glycerol:PBS (the PBS was adjusted to pH 9.0 with $\mathrm{Na}_{2} \mathrm{CO}_{3}$ and contained $10 \mathrm{mg} / \mathrm{ml}$ of 1,4-phenylenediamine to decrease fluorescence quenching), and stored at $4^{\circ} \mathrm{C}$ in the dark until vicwcd. Sections for immunoperoxidase were rinsed in $0.1 \mathrm{M} \mathrm{NaP}_{\mathrm{i}}, \mathrm{pH} 7.0$ $\left(\mathrm{NH}_{4} \mathrm{OH}\right)$, then incubated in the same buffer with $0.5 \%(\mathrm{wt} / \mathrm{vol}) 3,3^{\prime}-$ diaminobenzidine $4 \mathrm{HCl}(\mathrm{DAB})$ and $0.004 \%(\mathrm{wt} / \mathrm{vol}) \mathrm{H}_{2} \mathrm{O}_{2}$ for 3-10 min at room temperature. The DAB-reacted sections were rinsed with PBS, then mounted and coverslipped by standard procedures.

Solutions for immunohistochemical studies were preserved with $0.01-$ $0.1 \%(\mathrm{wt} / \mathrm{vol})$ thimerosal (Sigma). All rinses between antibody incubations were 3-5 times for 5 min with PBS. Immunohistochemical controls (preimmune serum and no primary antibody) were run with all tissues and processed identically with other sections. The concentration of preimmune serum always equaled or exceeded that of anti$\mathrm{CO}$. All incubations included gentle agitation.

\section{Results}

\section{Purification of $C O$ from calf brain}

A typical mitochondrial preparation from $131 \mathrm{gm}$ (wet weight) of calf brain cortex and caudate nuclei yielded $115 \mathrm{mg}$ of nonsynaptic mitochondrial protein and $65 \mathrm{mg}$ of synaptic mitochondrial protein. Separation of synaptic and nonsynaptic mitochondria was based on the density difference between synaptosomes and free (nonsynaptic) mitochondria. Synaptic mitochondria were then released from synaptosomes by hypotonic lysis (Rendon and Masmoudi, 1985). Electron microscopic examination revealed only mitochondria and no other recognizable subcellular organelles (e.g., myelin, synaptosomes) in our preparations (Fig. 1).

Both the synaptic and nonsynaptic mitochondrial populations were rich in $\mathrm{CO}$ activity and respiratory chain cytochromes (Table 1). CO comprised $8-9 \%$ of the mitochondrial protein, based on $10.0 \mathrm{nmol}$ heme a/mg protein in purified CO (Meinecke and Buse, 1985). Lai and Clark (1979) have reported cytochrome contents in synaptic and nonsynaptic rat brain mitochondria very different from those reported here. Our results probably reflect the better estimate, since the ratio of cytochromes $b / c_{1}$ was found to be $\sim 2$ in our samples but not in those of Lai and Clark (1979). This value matches the known composition of the $b c_{1}$ complex (respiratory complex III) in mitochondria (Vanneste, 1966) and in isolation (Hatefi, 1978).

The polypeptide compositions of the 2 mitochondrial preparations, analyzed electrophoretically, differed very little (data 

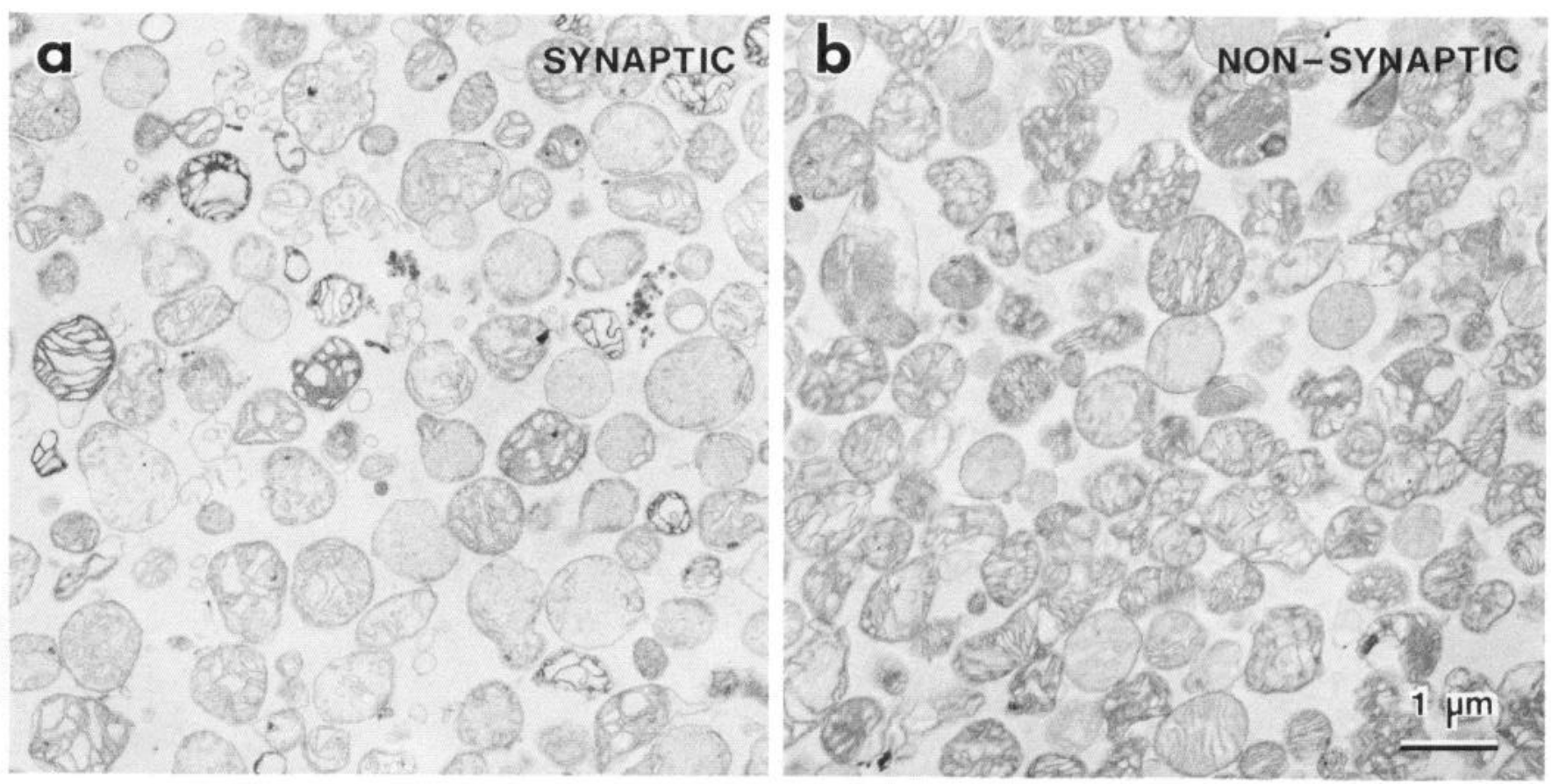

Figure 1. Mitochondria isolated from calf brain. The mitochondria were fixed in cold $2.5 \%$ paraformaldehyde, $1.5 \%$ glutaraldehyde, $4 \%$ sucrose,

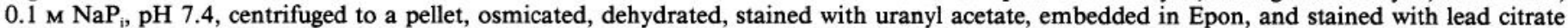
after thin sectioning. The synaptic mitochondria appear swollen compared with the nonsynaptic mitochondria, probably because of their exposure to hypotonic conditions during synaptosome lysis.

not shown). Only a few polypeptides (apparently unrelated to $\mathrm{CO})$ seemed to be unique to one or the other mitochondrial population. In sum, both mitochondrial populations contained high levels of $\mathrm{CO}$, differed little in their compositions, and appeared free of contamination by other organelles.

Results of a typical CO preparation from brain mitochondria are shown in Figure 2 and Table 2. Similar results were obtained in purifications of $\mathrm{CO}$ from bovine synaptic and nonsynaptic mitochondria and from crude bovine heart $\mathrm{CO}$. The chromatographic profile (Fig. 2) shows that $\mathrm{CO}$ (measured as heme a in cytochromes $a$ and $a_{3}$, the spectrophotometrically detectable redox centers of $\mathrm{CO}$ ) did not appear in any fractions during the loading or washing steps but only in elution fractions. The $\mathrm{CO}$ in this and other runs was eluted at $\mathrm{KP}_{\mathrm{i}}$ concentrations of 30$60 \mathrm{~mm}$. Surprisingly, cytochrome $c$ was also eluted by the salt gradient in every run, but cytochrome $b c_{1}$ never appeared in our elution fractions. Cytochrome $b c_{1}$, like $\mathrm{CO}$, binds to cytochrome $c$ and has been found in elution fractions by others using this method. Cytochrome $c$ has not been reported previously in elution fractions (Kuhn-Nentwig and Kadenbach, 1985; Broger et al., 1986). Methodological differences probably account for these discrepancies.

Table 2 shows overall purification results from the same batch shown in Figure 2. From a relatively small quantity of brain mitochondria ( $46 \mathrm{mg}$ protein), $400 \mu \mathrm{g} \mathrm{CO}$ were obtained at $99 \%$ purity (sufficient for immunizations). A striking loss of enzymatic activity occurred during the purification (Table 2), suggesting that the enzyme might have been denatured. However, Triton X-100 is known to inactivate $\mathrm{CO}$ by delipidation (Robinson and Capaldi, 1977) and, therefore, could also account for the loss of activity. Addition of soybean lecithin to the enzyme stimulated its activity severalfold (Table 2, Fig. 3), suggesting

Table 1. Cytochrome oxidase activity and cytochrome contents of mitochondria isolated from calf brain

\begin{tabular}{|c|c|c|c|c|c|c|}
\hline \multirow{3}{*}{$\begin{array}{l}\text { Mitochondrial } \\
\text { preparation }\end{array}$} & \multicolumn{2}{|c|}{$\begin{array}{l}\text { Cytochrome oxidase } \\
\text { specific activity } \\
\text { (units/mg protein) }\end{array}$} & \multirow{2}{*}{\multicolumn{4}{|c|}{$\begin{array}{l}\text { Specific content of mitochondrial cytochromes } \\
\text { (nmol/mg protein) }\end{array}$}} \\
\hline & \multirow{2}{*}{$\begin{array}{l}\text { Intact } \\
\text { mito- } \\
\text { chondria }\end{array}$} & \multirow{2}{*}{$\begin{array}{l}\text { Disrupted }{ }^{b} \\
\text { mito- } \\
\text { chondria }\end{array}$} & & & & \\
\hline & & & $a a_{3}$ & $b$ & $c_{1}$ & $c$ \\
\hline Nonsynaptic A & 0.77 & 5.39 & 0.907 & 0.353 & 0.170 & 0.532 \\
\hline Nonsynaptic B & 0.84 & 7.50 & 0.846 & 0.366 & 0.180 & 0.513 \\
\hline Synaptic A & 0.88 & 5.16 & 0.781 & 0.311 & 0.159 & 0.456 \\
\hline Synaptic B & 1.34 & 5.86 & 0.800 & 0.324 & 0.162 & 0.341 \\
\hline
\end{tabular}

${ }^{a}$ The letters $\mathrm{A}$ and $\mathrm{B}$ indicate separate preparations.

${ }^{b}$ Mitochondria were disrupted with an equal volume of $5 \%$ Triton X-100, $0.5 \mathrm{M} \mathrm{KP_{i } , \mathrm { pH }} 7.4$. 


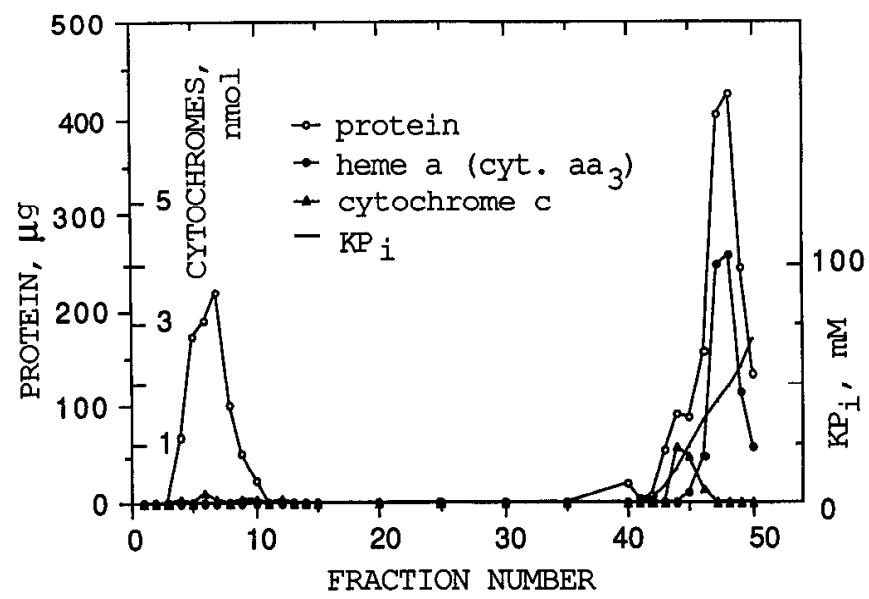

Figure 2. Cytochrome c-Sepharose 4B affinity chromatography purification of $\mathrm{CO}$. Crude $\mathrm{CO}(5.6 \mathrm{mg}$ protein) from brain nonsynaptic mitochondria was loaded on the column, washed with buffer, and eluted with a $\mathrm{KP}_{\mathrm{i}}$ gradient $(0-100 \mathrm{mM})$. Fractions $(2 \mathrm{ml})$ were assayed for $\mathrm{CO}$ activity (not shown) in addition to the quantities shown. Some $\mathrm{CO}$ activity came through the column in the loading phase but in amounts too small to be detectable as heme a. The fractions rich in heme a also were rich in $\mathrm{CO}$ activity. Cytochromes $b$ and $c$, were not detected in any fractions. The recovery of heme a in fractions $47-50$ was $72 \%$ of that loaded.

that lipid depletion was indeed responsible for the decreased activity. Full activity might have been restored if we had used a more potent (and more expensive) phospholipid activator of CO (Vik and Capaldi, 1980).

Analysis by urea-SDS-PAGE did not reveal any subunit mobility differences between $\mathrm{CO}$ isolated from synaptic versus nonsynaptic mitochondria (Fig. 4), suggesting that both populations contained the same single isozyme. Differences were seen between brain and heart $\mathrm{CO}$ in the mobilities of subunits VIa (see Fig. 6a) and VIII (data not shown), indicating that isozyme differences were detectable in our system. $\mathrm{CO}$ from bovine tissues may contain up to 13 subunits (Kadenbach et al., 1983), but only 10 subunits were resolved on our gels. (Subunits VIb and $c$ appeared as a single band, as did subunits VIIa, $b$, and c.) A few faint bands in the higher molecular weight range of both gels could not be identified as $\mathrm{CO}$ subunits. Such bands may have represented aggregation products of hydrophobic subunits of the enzyme (Kadenbach et al., 1983) or impurities.

Given these uncertainties, heme a/protein ratios were the primary criterion used in assessing enzyme purity. The brain

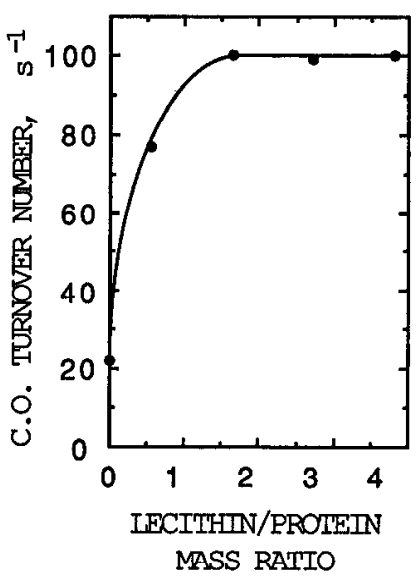

Figure 3. Activation of $\mathrm{CO}$ by soybean lecithin. Purified Triton $\mathrm{X}-100$ solubilized brain $\mathrm{CO}(9.9 \mathrm{nmol} \mathrm{hcmc} \mathrm{a} / \mathrm{mg}$ protein) was sonicated for $5 \mathrm{sec}$ with increasing amounts of crude lecithin (Sigma Type IV-S, soybean lecithin, $35 \% \mathrm{~L}-\alpha$-phosphatidylcholine) and assayed for activity. Control assays showed that the lecithin by itself contained no $\mathrm{CO}$ activity.

$\mathrm{CO}$ preparations were of high purity by the criterion of heme a/protein ratio and, as shown above, appeared to be homogeneous; i.e., only one isozyme of brain $\mathrm{CO}$ was detected.

\section{Antibody specificity}

All antibodies used in this study came from one rabbit. The antibrain $\mathrm{CO}$ titer (all titers were determined by ELISA) in the animal's serum was undetectable before the first immunization, $1: 50$ in the week preceding the booster immunization, and 1:100,000 2 weeks after the booster (Fig. $5 a$ ). The titer remained at 1:100,000 in all subsequent bleeds, the last of which was taken 7 months after the booster. The antibodies had a similar titer against bovine heart $\mathrm{CO}$ (data not shown). Indirect immunoprecipitation experiments showed that the antibodies were capable of reacting with enzymatically active $\mathrm{CO}$ (Fig. $5 b$ ) as well as $\mathrm{CO}$ on ELISA plates. Active $\mathrm{CO}$ from both brain and heart was precipitated.

The antibodies not only reacted with $\mathrm{CO}$, but also were specific for CO, as shown by SDS immunoblot analysis (Fig. 6a). The major immunoreactive band was identified as $\mathrm{CO}$ subunit IV based on (1) the presence of the band in lanes containing purified $\mathrm{CO}$, and (2) the migration distance of the band, which was identical to that of $\mathrm{CO}$ subunit IV in silver-stained lanes from the same gel. Subunits I and II also showed slight immunoreactivity.

Table 2. Cytochrome oxidase purification from calf brain nonsynaptic mitochondria

\begin{tabular}{|c|c|c|c|c|c|}
\hline Fraction & $\begin{array}{l}\text { Protein } \\
\text { (mg) }\end{array}$ & $\begin{array}{l}\text { Heme a } \\
(\mathrm{nmol})\end{array}$ & $\begin{array}{l}\text { Purity }^{a} \\
\text { (nmol } \\
\text { heme } \\
\text { a/mg } \\
\text { protein) }\end{array}$ & $\begin{array}{l}\text { Yield } \\
\text { (\% heme a) }\end{array}$ & $\begin{array}{l}\text { Turnover } \\
\text { number } \\
\left(\sec ^{-1}\right)\end{array}$ \\
\hline Mitochondria & 45.9 & 38.9 & 0.9 & 100 & $33(269)^{b}$ \\
\hline Applied to affinity column & 5.6 & 15.1 & 2.7 & 39 & 168 \\
\hline Affinity chromatography fractions $47-50$ & 1.2 & 10.9 & 9.1 & 28 & $21(100)^{c}$ \\
\hline Affinity chromatography fraction 47 & 0.40 & 4.0 & 9.9 & 10 & $24(100)^{c}$ \\
\hline
\end{tabular}

a Purified CO contains $10 \mathrm{nmol}$ heme a/mg protein.

${ }^{b}$ Activity after mitochondrial disruption with Triton $\mathrm{X}-100$ given in parentheses.

c Activity after sonication with soybean lecithin given in parentheses. 


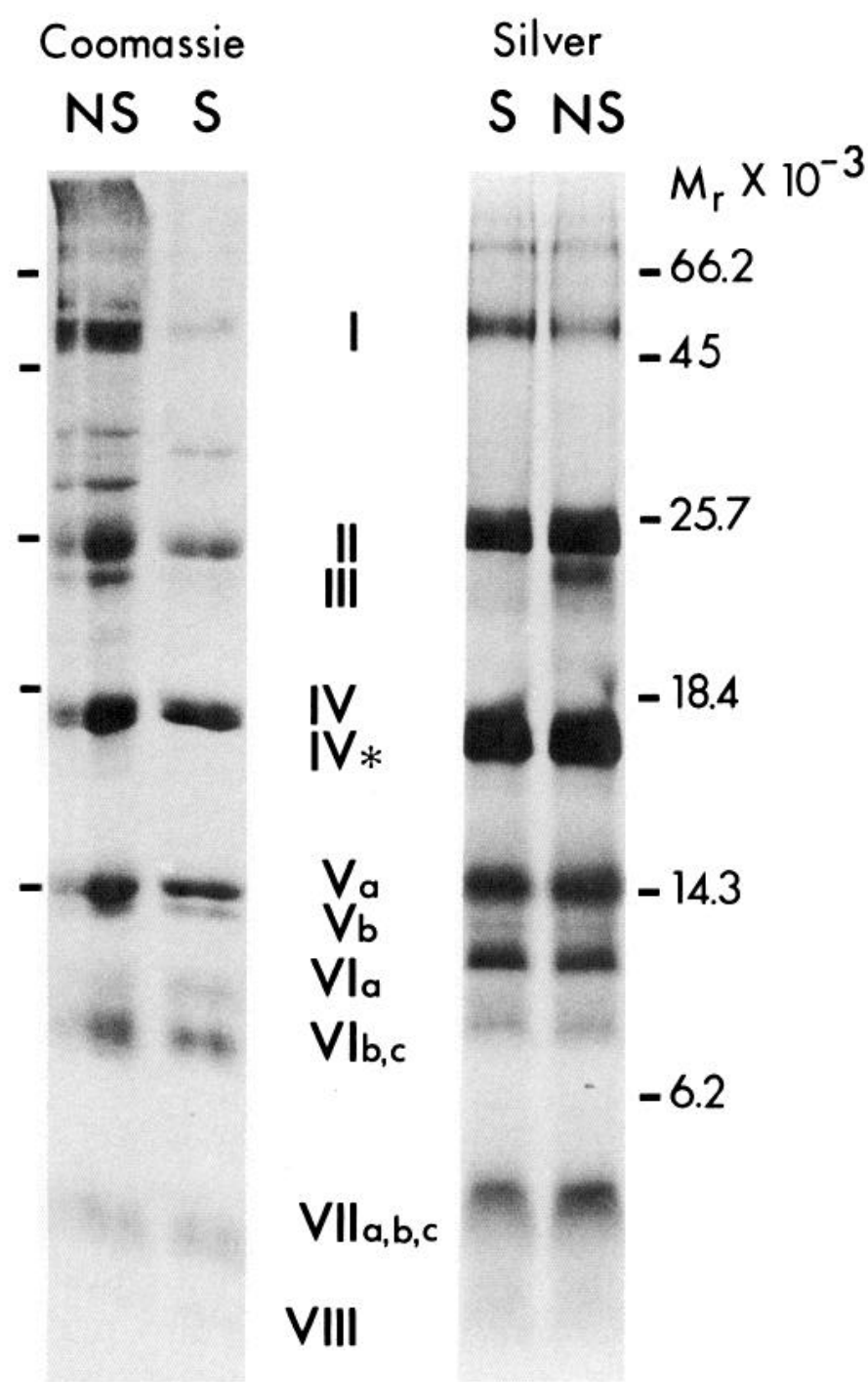

Figure 4. Subunit composition of $\mathrm{CO}$ purified from synaptic $(S)$ and nonsynaptic $(N S)$ mitochondria. The two gels (both $18.6 \% \mathrm{~T}, 3.0 \% \mathrm{C}$ ) contained different preparations of $\mathrm{CO}$ and were stained with Coomassie blue (Serva Blue R) or ammoniacal silver as indicated. Both gels are shown, since each highlighted different subunits more clearly. The positions of molecular weight markers are shown for each gel. Subunit III was not always visible in these or other gels. It is hydrophobic and sometimes aggregates during sample preparation. Subunits VIa and VIII are thought to be isozyme-specific but did not differ in their mobilities between the $\mathrm{S}$ and NS CO preparations. These subunits did show mobility differences between bovine brain and heart $\mathrm{CO}$ preparations (Fig. $6 a$ and data not shown). In labeling the bands, it was assumed that 13 subunits were present but were not resolved (Kadenbach et al., 1983). The band labeled $I V^{*}$ has been shown to be a proteolytic degradation product of subunit IV (Merle et al., 1981). Each lane contained $35 \mu \mathrm{g}$ protein on the Coomassie-stained gel and $7.5 \mu \mathrm{g}$ protein on the silverstained gel.

As in the ELISA and indirect immunoprecipitation experiments, the antibodies reacted in immunoblots with both heart and brain $\mathrm{CO}$ (Fig. $6 a$ ). All of our immunochemical data thus agree in showing tissue cross-reactivity. A separate immunoblot experiment (Fig. $6 b$ ) showed that the antibodies also cross reacted with $\mathrm{CO}$ from different species. Brain CO subunit IV from monkey, mouse, cat, dog, rat, and even rabbit (in which species the antibodies were raised) were all immunoreactive. The detection limit of the immunoblot procedure (Fig. $6 b$ ) was between
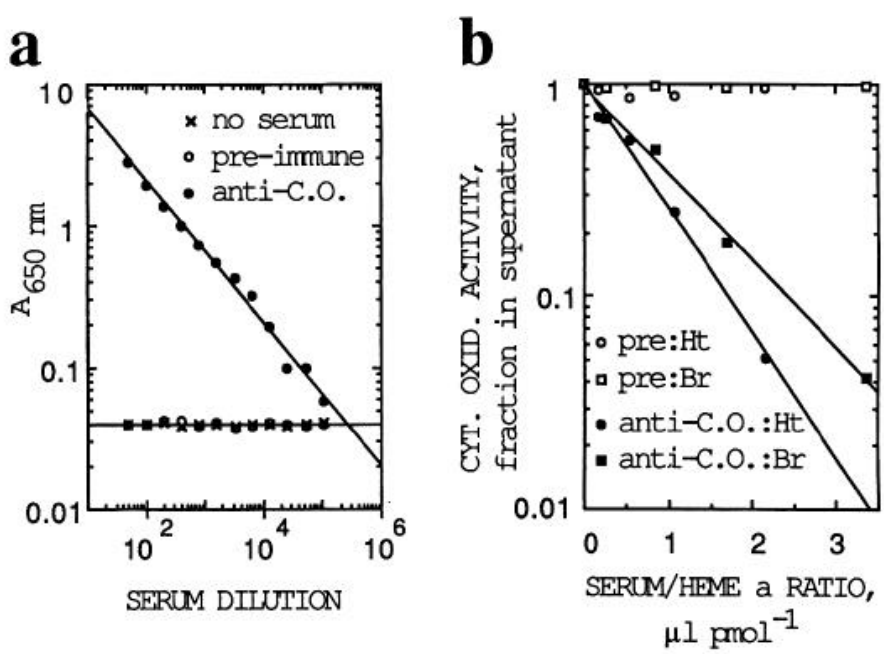

Figure 5. Detection of antibodies against CO. $a$, ELISA showing that antibodies to $\mathrm{CO}$ were detectable in antiserum diluted $1: 100,000$. Purified bovine brain $\mathrm{CO}$ was bound to polystyrene wells and allowed to react sequentially with anti-CO and GaR-HRP. The optical absorbance of the colored HRP reaction product was determined with a microplate reader. The antibodies also reacted with purified bovine heart $\mathrm{CO}$ in ELISA (not shown). $b$, Indirect immunoprecipitation of $\mathrm{CO}$ activity by anti-CO. The antibodies were bound to protein A-Sepharose CL-4B beads, then mixed with solubilized active $\mathrm{CO}$ from bovine heart $(\mathrm{Ht})$ or brain $(\mathrm{Br})$. The beads were pelleted, and $\mathrm{CO}$ activity was determined in the supernatant.

0.1-1.0 $\mu \mathrm{g}$ calf brain $\mathrm{CO}$ holoenzyme, which corresponds to 8.4-84 ng subunit IV (Kadenbach et al., 1987).

To summarize, the anti-CO exhibited the following properties in biochemical tests: (1) high titer, (2) reactivity with both active and inactive $\mathrm{CO}$, (3) specificity for $\mathrm{CO}$, especially subunit IV; and (4) cross-reactivity among all mammals tested.

The antibodies also reacted specifically with $\mathrm{CO}$ in immunohistochemistry. Strong staining was seen in mouse and monkey brain tissues when anti-CO was used for immunohistochemistry but not when either anti-CO preabsorbed with $\mathrm{CO}$ or preimmune serum was used. Only low-level, nonspecific background staining was then seen (Fig. 7). Controls had low backgrounds whether the immunoperoxidase or the immunofluorescence method was used. The specificity and intensity of the immunohistochemical staining depended partly on the fixation and incubation conditions. Tissue fixed by perfusion or with glutaraldehyde usually had more nonspecific staining and less specific staining. Immersion fixation with paraformaldehyde always gave good results.

\section{CO immunohistochemistry: correlation with histochemistry}

Brain regions with well-defined, characteristic patterns of $\mathrm{CO}$ histochemical activity were selected for immunohistochemical analysis. The pattern of immunohistochemical labeling in each region was then compared with the pattern of $\mathrm{CO}$ histochemistry. In comparing the results, we refer to histochemical reactivity as "activity" of $\mathrm{CO}$ and to immunohistochemical reactivity as "amount" of $\mathrm{CO}$. Reasons for equating immunohistochemical reactivity with $\mathrm{CO}$ amount will be given in the Discussion.

A typical and unmistakable match between the histochemical and immunohistochemical patterns was seen in the mouse somatosensory "barrel" cortex (Fig. 8). Both the activity and the amount of $\mathrm{CO}$ were enriched in the barrel hollows versus the 
Figure 6. Immunoblot analysis of anti$\mathrm{CO}$ specificity. $a$, Different lanes from the same gel $(18.6 \% \mathrm{~T}, 3.0 \% \mathrm{C})$ were stained with silver to show $\mathrm{CO}$ subunits or transferred to nitrocellulose to show immunoreactive polypeptides, as indicated. Molecular weight marker positions are shown at the right. Bands immunoreactive with anti-CO are identified with large arrowheads; an unidentified immunoreactive band in lane 6 is indicated with a small arrowhead. This unidentified band appeared only in this lane and was relatively faint. It may have comprised aggregates of hydrophobic $\mathrm{CO}$ subunits. Note that brain (lane 1) and heart (lane 2) $\mathrm{CO}$ show a difference in the migration of subunit VIa. Lanes 1 and $3,15 \mu \mathrm{g}$ partially purified bovine brain CO. Lanes 2 and 4 , $15 \mu \mathrm{g}$ partially purified bovine heart $\mathrm{CO}$. Lane 5, SDS-solubilized mouse caudate nucleus ( $\sim 50 \mu \mathrm{g}$ protein). Lanes 6 and 8, SDS-solubilized brain mitochondria ( $50 \mu \mathrm{g}$ protein). Lane 7 , crude bovine heart $\mathrm{CO}(40 \mu \mathrm{g}$ protein). $b$, The anti-CO recognized $\mathrm{CO}$ subunit IV in SDS-solubilized caudate nucleus from mouse (lane 4), rat (lane 5), dog (lane 6), cat (lane 7), monkey (lane 8), and rabbit (lane 9). Only subunit IV was visible in this blot. The slightly different mobilities of the immunoreactive bands probably reflect interspecies differences in the size of CO subunit IV. Lanes 13 and 10 contained purified bovine brain $\mathrm{CO}$ (lane 1: $0.1 \mu \mathrm{g}$; lane 2: $1.0 \mu \mathrm{g}$; lanes 3 and 10 : $10 \mu \mathrm{g}$ ). Lanes 4-9 each contained $\sim 75 \mu \mathrm{g}$ protein.

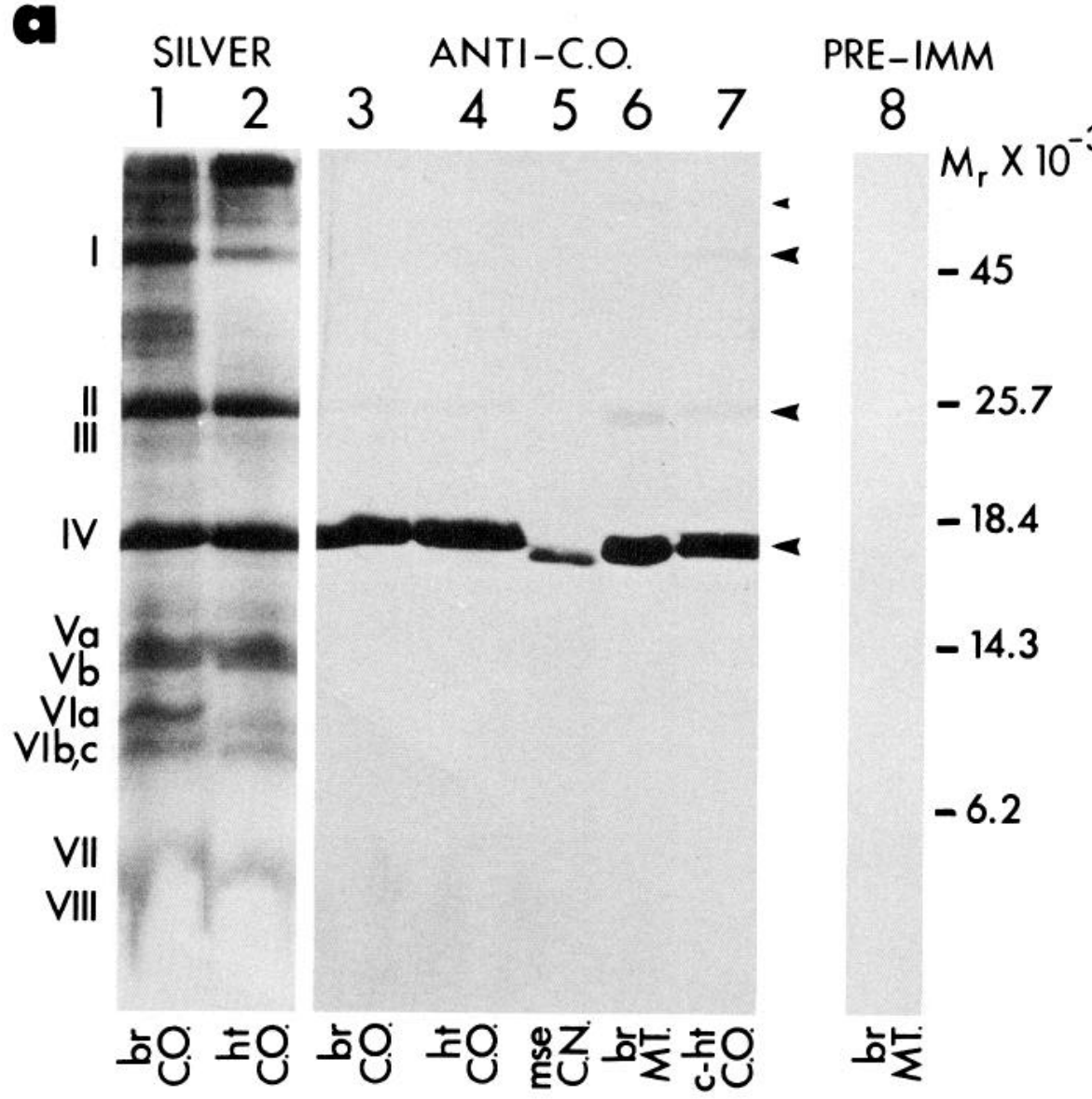

b

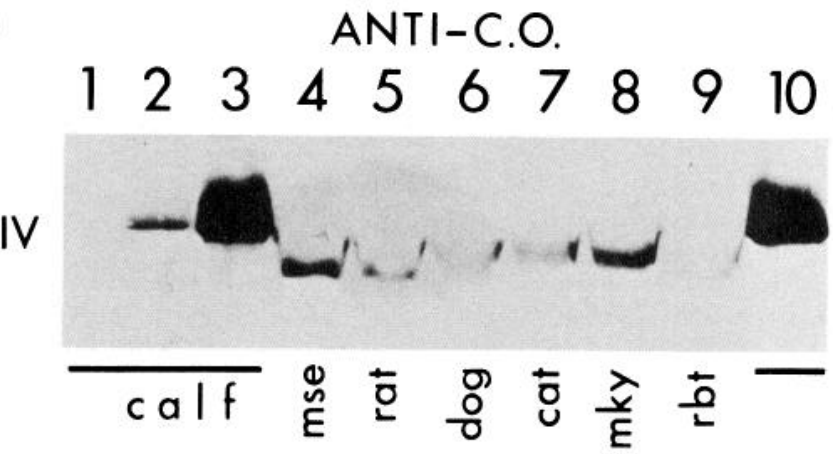

barrel septa, forming the well-known pattern of 5 barrel rows in the posteromedial barrel subfield (Woolsey and van der Loos, 1970). The only difference between the 2 patterns was that the $\mathrm{CO}$ histochemistry showed a higher degree of contrast between the hollows and septa than did the $\mathrm{CO}$ immunohistochemistry. This contrast difference between the 2 methods was found consistently in other brain regions as well.

In the mouse olfactory bulb, the patterns of $\mathrm{CO}$ amount (in this case shown as immunofluorescence) and $\mathrm{CO}$ activity again matched (Fig. 9). The plexiform layers and the glomeruli were most reactive, whereas the axon-rich regions and the mitral cell body layer were less reactive. Both staining methods revealed that not all glomeruli were equally rich in $\mathrm{CO}$. Apparently, individual glomeruli maintain different levels of neural functional activity.
The distributions of $\mathrm{CO}$ histochemical and immunohistochemical labeling in the mouse cerebellum likewise matched and contrasted with the distribution of cell bodies, shown by a Nissl stain (Fig. 10). The cerebellum as a whole (Fig. 10a-c) had the highest levels of $\mathrm{CO}$ amount and activity in the cortex and deep nuclei. White matter (as is invariably the case) stained very lightly by both methods. Within the cerebellar cortex (Fig. $10 d-f$ ), the CO histochemical and immunohistochemical methods both showed punctate staining in the molecular layer, pericellular labeling around the Purkinje cells, and intense patchy staining in the granule cell layer. Cells in the molecular layer were visible by $\mathrm{CO}$ immunohistochemistry but not histochemistry. Examination of the deep cerebellar nuclei at higher magnification (Fig. 10g-i) revealed that high levels of $\mathrm{CO}$ amount and activity were present in neurons as well as in the neuropil. 

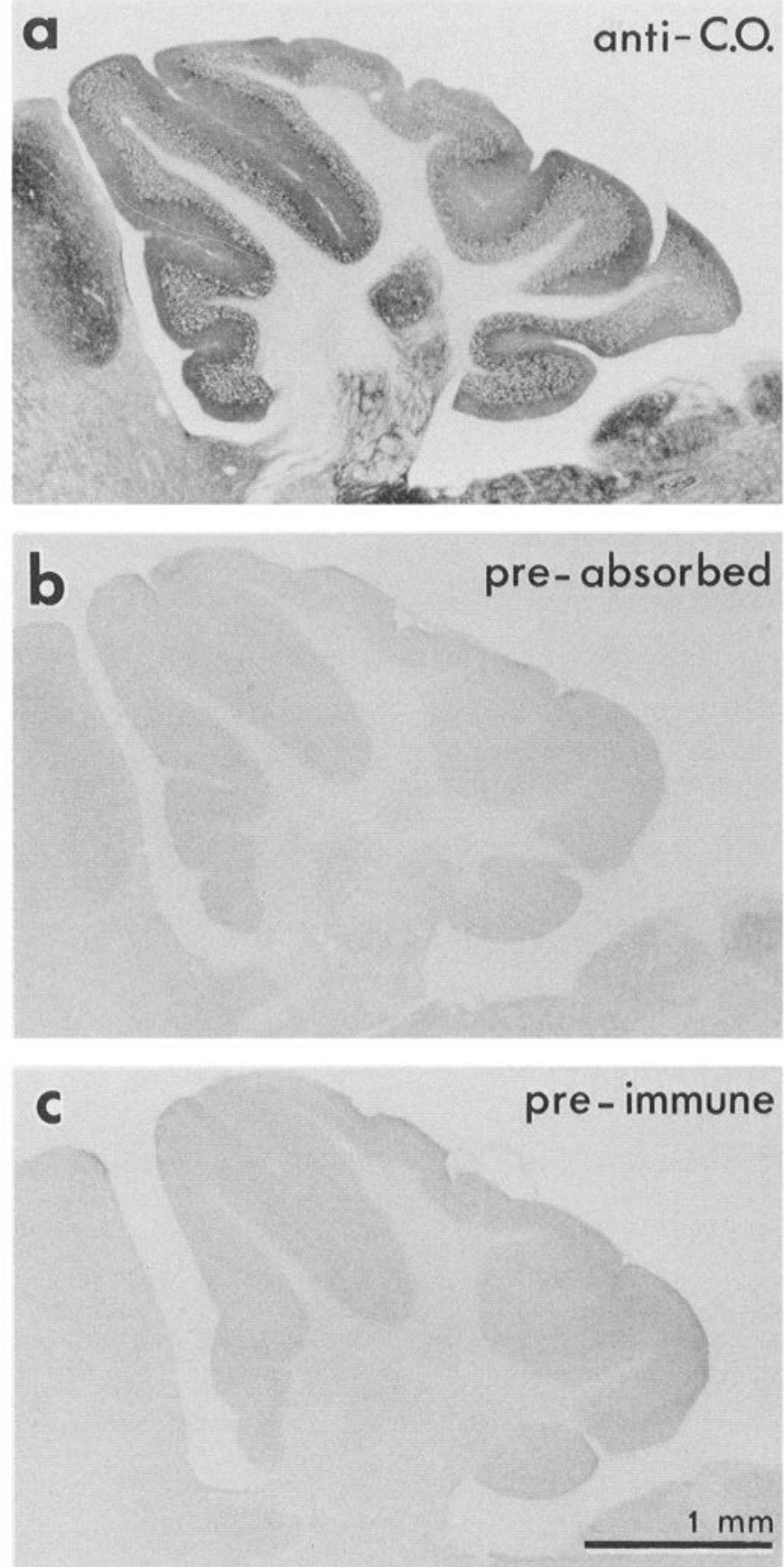

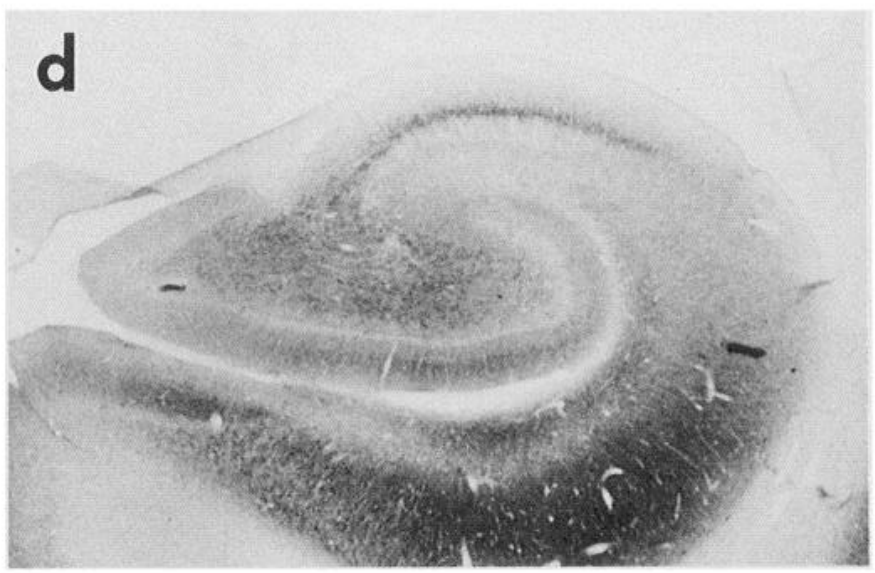

e

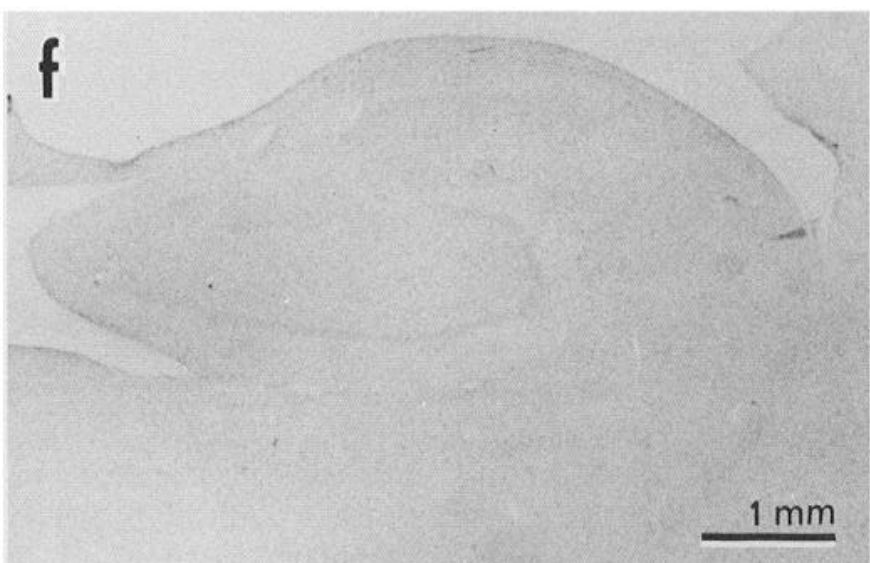

Figure 7. Specificity of $\mathrm{CO}$ immunohistochemistry in both the mouse and the monkey brain. Neighboring frozen sections from the same block of mouse cerebellum $(a-c)$ or monkey hippocampus $(d-f)$ were processed for immunohistochemistry with anti-CO $(1: 8000 ; a$ and $d)$, anti-CO preabsorbed with purified $\mathrm{CO}(1: 8000 ; b$ and $e$ ), or preimmune serum $(1: 5000 ; c$ and $f)$. The sections were further incubated with GaR-HRP and reacted with DAB. Sections of cerebellum were cut in a parasagittal plane at $20 \mu \mathrm{m}$. Hippocampus sections were cut perpendicular to the long axis of the formation at $30 \mu \mathrm{m}$. The low-level nonspecific background staining seen in preimmune and preabsorbed control sections appeared at higher magnification to be localized to glial processes. Similar control results were obtained using the immunofluorescence method.

The pattern of $\mathrm{CO}$ histochemistry in the mouse cerebellum was very similar to that seen in a previous light and electron microscopic study of the rat cerebellum (Mjaatvedt and WongRiley, 1988). In that study, the punctate staining of the molecular layer was localized to Purkinje cell dendrites, the pericellular labeling around Purkinje cells was localized to presumptive basket cell terminals, and the patchy staining in the granule cell layer was localized to mossy fiber terminals. Presumably, these same neuronal elements were CO-reactive histochemically and immunohistochemically in this study of the mouse.

The distributions of $\mathrm{CO}$ amount and activity in the monkey hippocampus were, as in regions of the mouse brain, very similar to each other, and very different from the distribution of cells (Fig. 11). The white matter regions all showed low CO levels, whereas the highest levels of $\mathrm{CO}$ amount and activity were seen in the outer portion of the dentate molecular layer, the CA3 

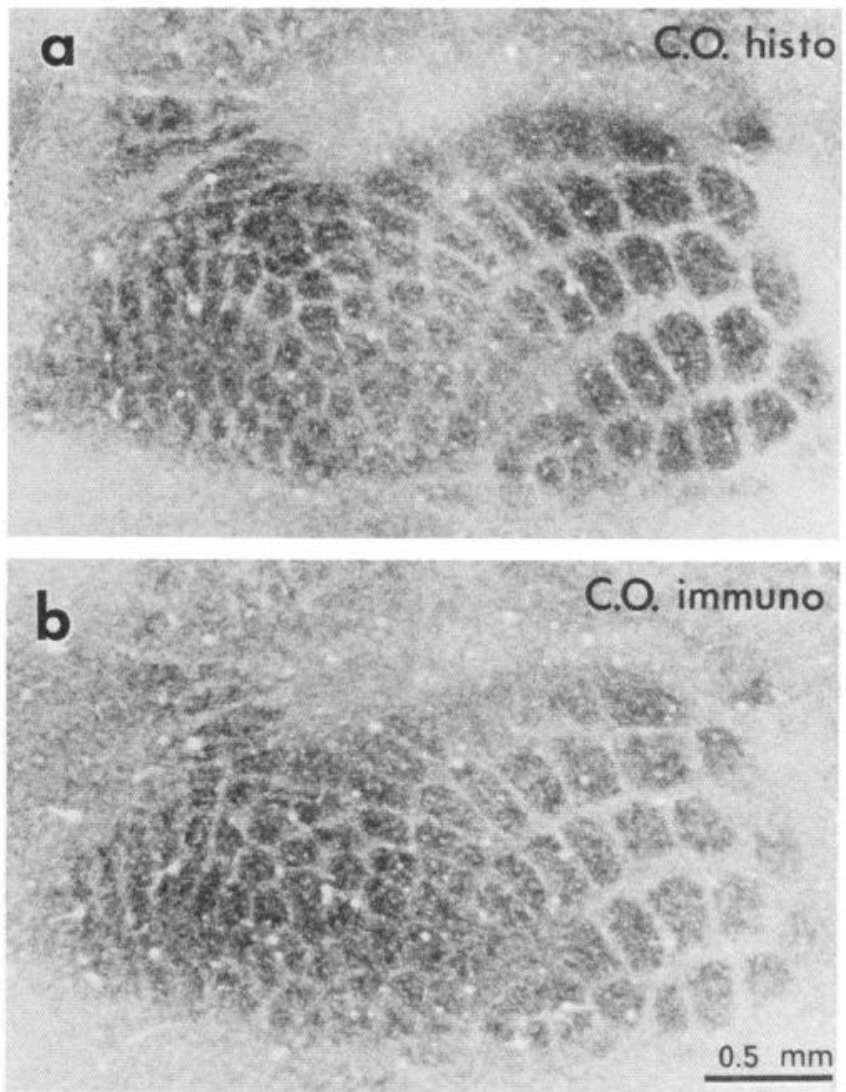

Figure 8. Correlation of $\mathrm{CO}$ activity and amount distributions in the mouse somatosensory (barrel) cortex. Adjacent frozen sections $(20 \mu \mathrm{m})$ processed for $\mathrm{CO}$ histochemistry $(a)$ and $\mathrm{CO}$ immunohistochemistry $(b)$ are shown. Sections were cut in a plane tangential to the cortical surface; the cortex was flattened before sectioning. The section shown in $b$ was incubated with anti-CO at 1:8000, then visualized with GaR-HRP and DAB. Both sections were photographed and printed with the same degree of contrast.

pyramidal cell layer, and the CA1 molecular layer. This same distribution of $\mathrm{CO}$ histochemical activity is found in the hippocampus of many mammalian species (Kageyama and WongRiley, 1982). Distinctive patterns of CO histochemistry are also found on a finer scale in several subregions of the hippocampus (Kageyama and Wong-Riley, 1982). These distinctive patterns were visible by both $\mathrm{CO}$ histochemistry and immunohistochemistry in this study.

In the dentate gyrus, for example, a marked difference was seen between the outer and inner portions of the molecular layer in both $\mathrm{CO}$ histochemical activity and $\mathrm{CO}$ immunohistochemical amount (Fig. 11). Darkly stained ascending dendrites were prominent in the outer but not the inner molecular layer of the dentate gyrus. As noted previously (Kageyama and Wong-Riley,
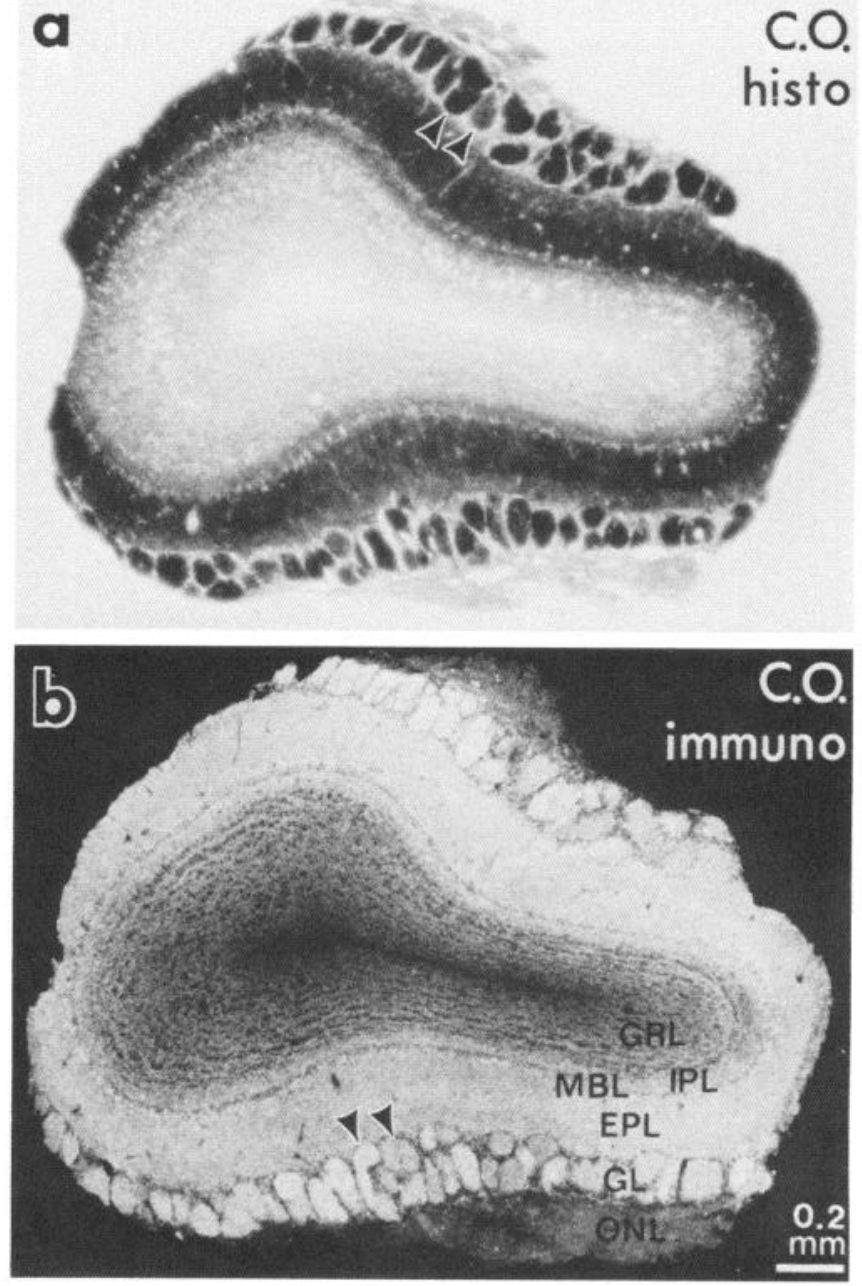

Figure 9. Correlation of $\mathrm{CO}$ activity and amount distributions in the mouse olfactory bulb. Neighboring coronal frozen sections $(20 \mu \mathrm{m})$ processed for CO histochemistry $(a)$ and $\mathrm{CO}$ immunohistochemistry $(b)$ are shown. Section $b$ was incubated with anti-CO at 1:2000 and visualized with fluorescent second and third antibodies. The arrowheads indicate adjacent glomeruli, which stained with different intensities. $O N L$, olfactory nerve layer; $G L$, glomerular layer; $E P L$, external plexiform layer; $M B L$, mitral body layer; $I P L$, internal plexiform layer; $G R L$, granule cell layer.

1982), the darkly stained part of the dentate molecular layer receives strong excitatory synaptic input from the perforant pathway (Swanson, 1982).

The patterns of $\mathrm{CO}$ histochemistry and immunohistochemistry in hippocampal subfield CA3 also were distinctive and followed the previously described histochemical pattern (Kageyama and Wong-Riley, 1982). Neurons of the pyramidal cell layer were darkly stained for $\mathrm{CO}$ activity and amount, as were

Figure 10. Correlation of $\mathrm{CO}$ activity and amount distributions in the mouse cerebellum. Adjacent parasagittal frozen sections (20 $\mu \mathrm{m})$ were stained with cresyl violet $(a, d, g), \mathrm{CO}$ histochemistry $(b, e, h)$, or CO immunohistochemistry $(c, f, i)$. The section stained by CO immunohistochemistry was incubated with anti-CO at $1: 8000$, then processed with GaR-HRP and DAB. Views of the cerebellar cortex $(d-f)$ and deep nuclei $(g-l)$ are higher magnifications of the corresponding sections shown in $a-c$. The arrowheads in $e$ and $f$ indicate dense labeling around (but not in) the Purkinje cell bodies. The labeling probably corresponds to basket cell terminals. The arrows in $f$ indicate cell bodies stained immunohistochemically (but not histochemically) in the molecular layer. $M L$, molecular layer; $P C L$, Purkinje cell layer; $G C L$, granule cell layer. 


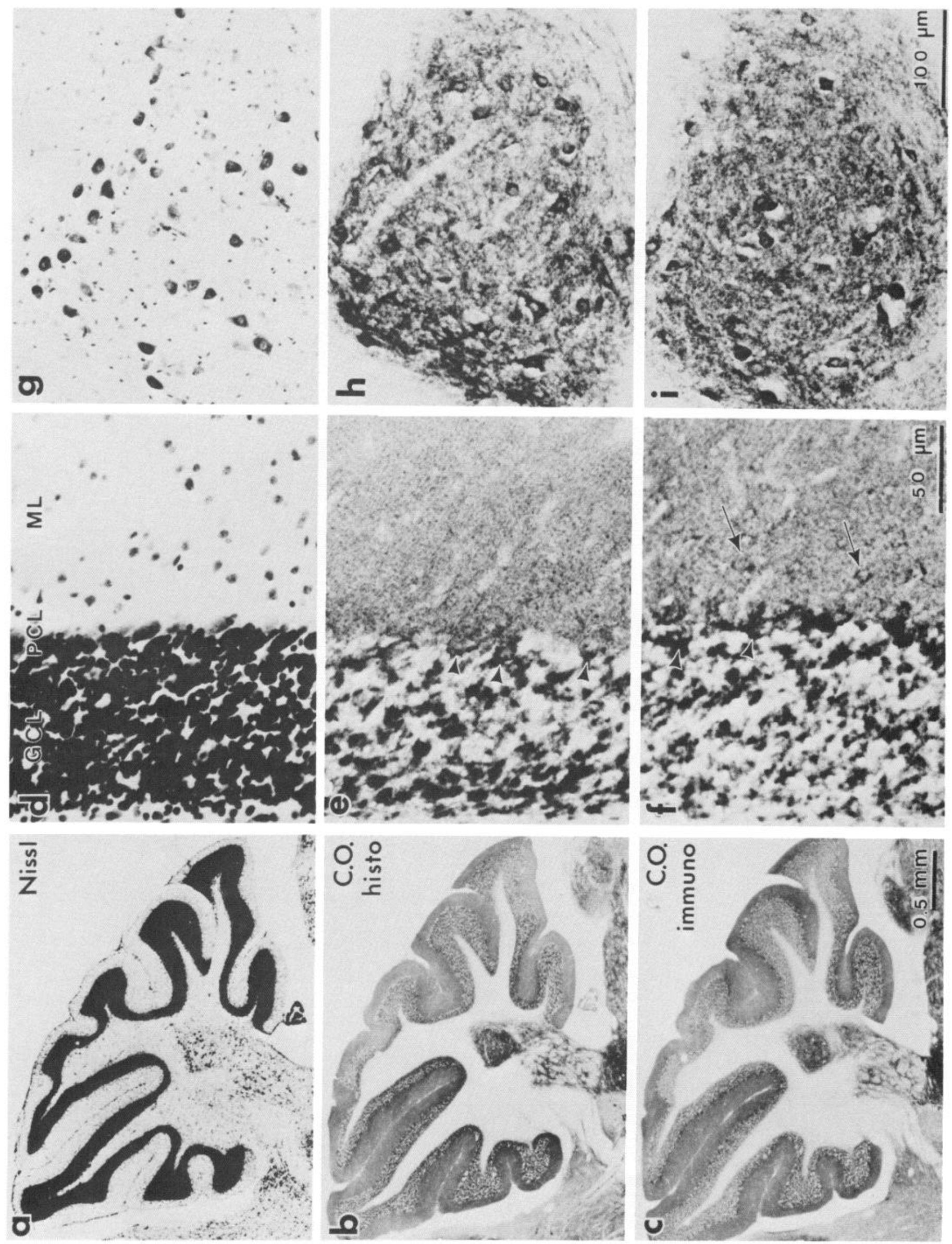




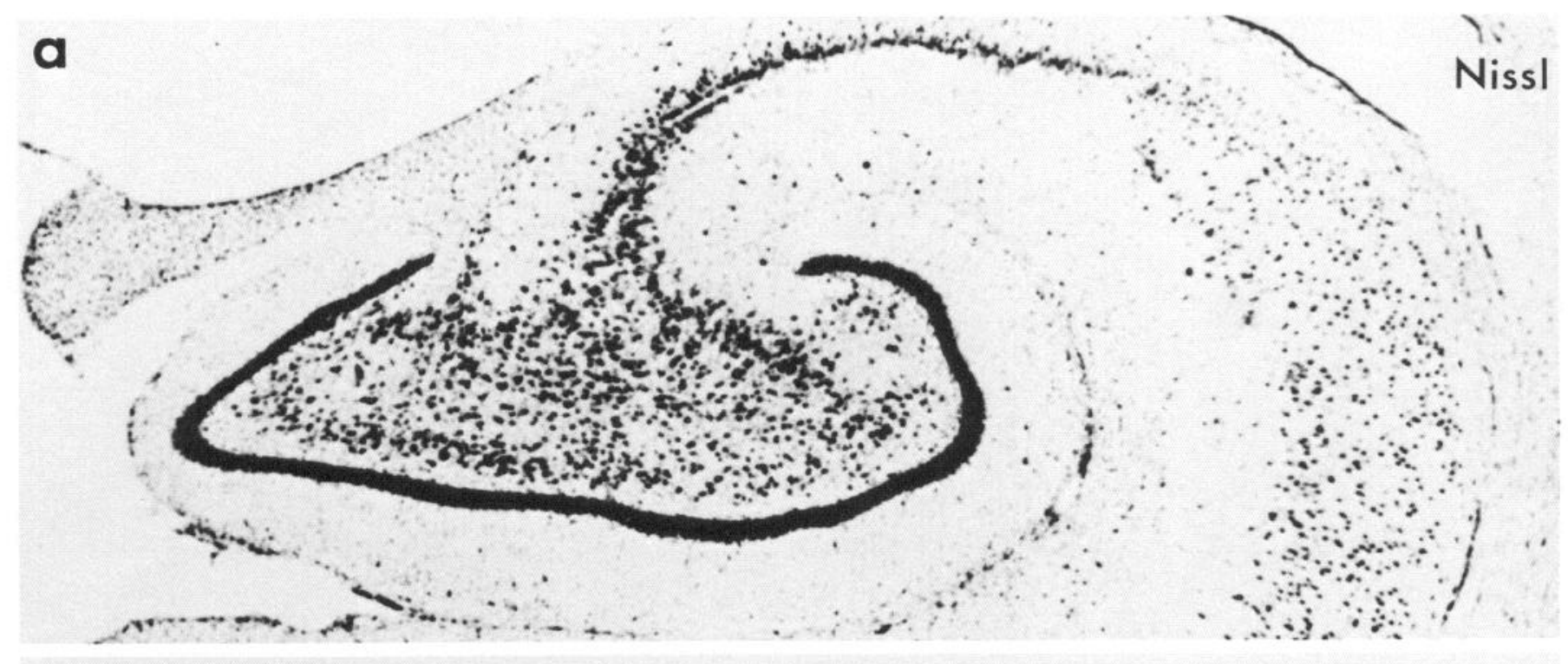

b

C.O. histo

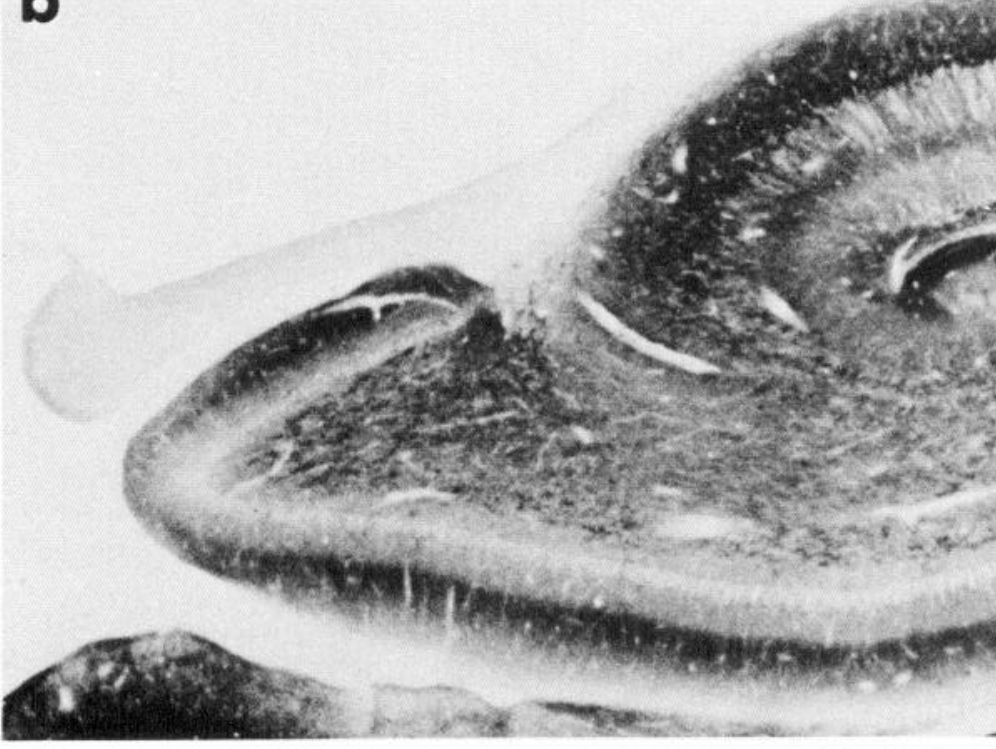

C
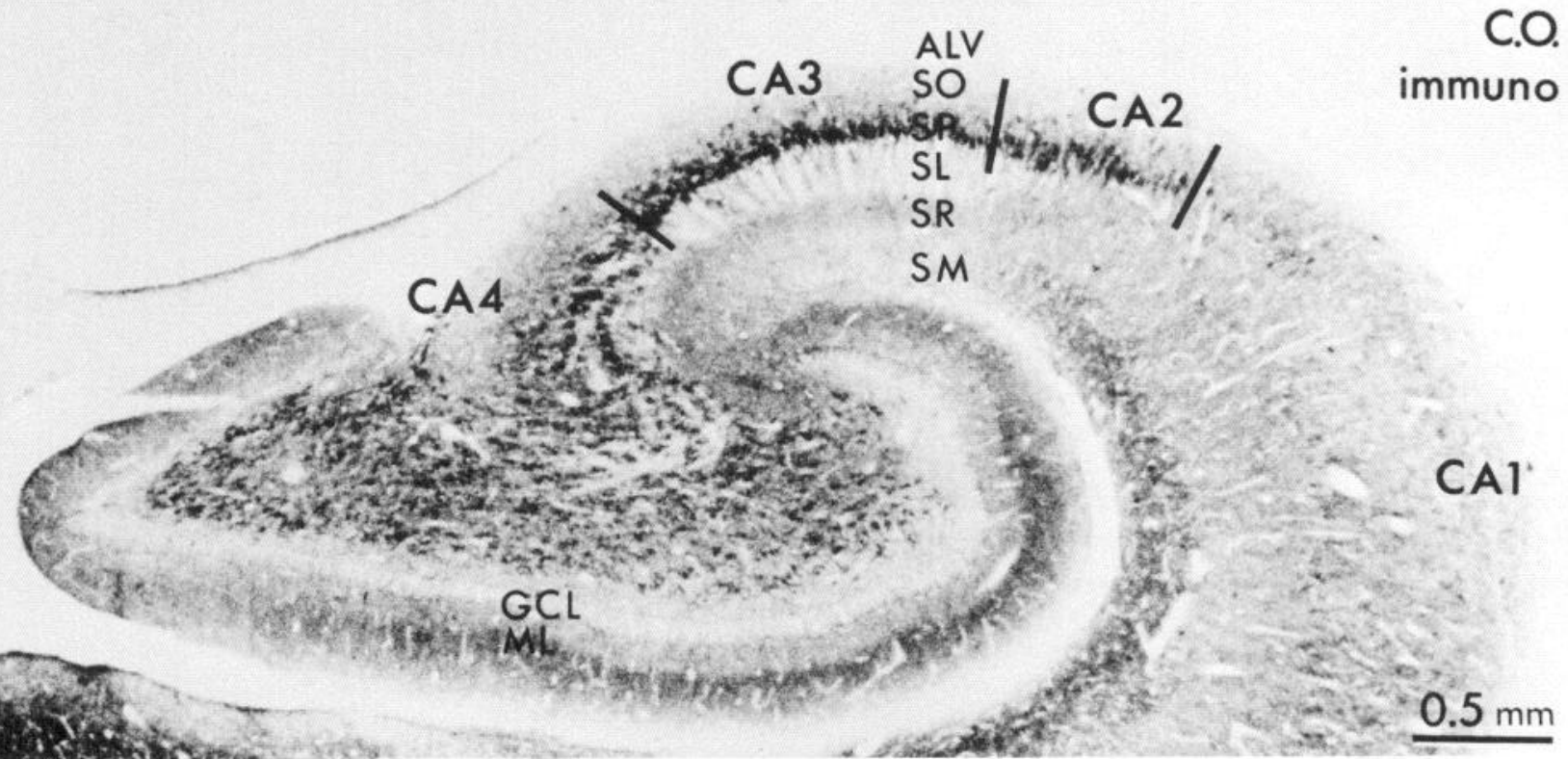
their apical dendrites, which ascended through the overlying stratum lucidum. The stratum lucidum was relatively unreactive except for the pyramidal cell apical dendrites. The stratum radiatum and the stratum oriens had moderate levels of $\mathrm{CO}$ amount and activity. These regional differences in $\mathrm{CO}$ activity and amount were unrelated to the density of cells in CA3, as seen by comparison with the Nissl-stained section.

To summarize the immunohistochemical results, strong correlations were observed between the distributions of $\mathrm{CO}$ histochemical activity and immunohistochemical amount in each brain region examined. The correlations were observed in several brain regions from two mammalian species. Other patterns within the tissues, such as the distribution of cells, differed from the pattern of $\mathrm{CO}$ distribution.

\section{Discussion}

\section{CO purification from brain}

$\mathrm{CO}$ has been isolated from porcine brain for use in analytical studies (Kuhn-Nentwig and Kadenbach, 1985; Kadenbach et al., 1986) but is more easily isolated from other organs. Purification of brain $\mathrm{CO}$ was considered necessary for this study because immunochemical differences exist among $\mathrm{CO}$ from different tissues, including brain (Kuhn-Nentwig and Kadenbach, 1985). The tissue-specific immunochemical properties of CO, along with other evidence, suggest that $\mathrm{CO}$ exists as several isozymes in mammals (Kadenbach et al., 1986, 1987).

The possibility that brain tissue might itself contain more than one isozyme of $\mathrm{CO}$ was considered. More than one isozyme of other metabolic enzymes, including lactate dehydrogenase (Maker et al., 1972) and 6-phosphofructo-1-kinase (Dunaway and Kasten, 1988), are present in brain tissue. We were able to detect only one isozyme of $\mathrm{CO}$ in brain by electrophoretic comparison of subunit profiles of $\mathrm{CO}$ from synaptic and nonsynaptic mitochondria.

The purity of our CO preparations was confirmed by heme $\mathrm{a} /$ protein ratio and by gel electrophoresis. Data from protein sequencing (Meinecke and Buse, 1985) and gel electrophoresis (Kadenbach et al., 1983) are consistent in indicating that 1213 subunits are present in bovine heart $\mathrm{CO}$ and that the specific heme a content is $10 \mathrm{nmol}$ heme a/mg protein. Disagreement does exist, however, over both the subunit composition (Kadenbach et al., 1983, 1987; Saraste, 1983) and the specific heme a content (Hartzell et al., 1978; Ozawa et al., 1982; Meinecke and Buse, 1985) of the purified enzyme. The activity of the purified enzyme was low but was restored by activation with soybean lecithin (Fig. 3), indicating that delipidation rather than denaturation was responsible for the low activity (Robinson and Capaldi, 1977).

Antibody specificity

Antibodies against $\mathrm{CO}$ were detected by their abilities to bind $\mathrm{CO}$ in ELISA assays (Fig. 5a) and to immunoprecipitate active, solubilized $\mathrm{CO}$ (Fig. $5 b$ ). The antibodies were highly specific in SDS immunoblots for subunit IV of the enzyme, less reactive with subunits I and II, and unreactive with other subunits (Fig. $6 a$ ). A prevalence of antibodies to subunit IV also has been reported by other groups (Nakagawa and Miranda, 1987; Nicholls et al., 1988), although Jarausch and Kadenbach (1982) succeeded in generating antibodies to all of the subunits. The antibodies reacted with $\mathrm{CO}$ subunit IV from several mammalian species besides cow (Fig. $6 b$ ), indicating that this protein has been conserved. The antibodies furthermore cross-react not only in blots but also immunohistochemically with cat and rat brain CO (R. F. Hevner, X. Luo, and M. T. T. Wong-Riley, unpublished observations), as well as with monkey and mouse brain $\mathrm{CO}$ (this study). We have not tested nonmammalian species for cross-reactivity.

Immunohistochemical specificity of the antibodies was confirmed by the absence of staining when preabsorbed anti-CO or preimmune serum was substituted for anti-CO (Fig. 7). Also, the only immunoreactive peptide detectable in SDS-solubilized brain tissue was CO subunit IV (Fig. 6, $a, b$ ). Our conclusion that the antibodies were $\mathrm{CO}$-specific was reinforced by the correlation found between the histochemical and immunohistochemical distributions of $\mathrm{CO}$ (Figs. 8-11).

It could be argued that the immunohistochemical distribution of subunit IV might not match that of CO holoenzyme. Subunit IV, however, has a 1:1 stoichiometric ratio with purified CO holoenzyme (Merle and Kadenbach, 1980), so their distributions should match. Newly synthesized subunit IV, not yet incorporated into $\mathrm{CO}$ holoenzyme at the time of tissue fixation, might also be detected immunohistochemically, but since $\mathrm{CO}$ turns over with a half-life of 5-7 days (rat liver, in vivo; Ip et al., 1974), the proportion of unincorporated, newly synthesized subunit IV in tissue is probably insignificant in most areas.

The results of our biochemical and immunohistochemical studies suggest that the antibodies specifically label $\mathrm{CO}$, whether active or inactive, in immunohistochemistry. Biochemically, the antibodies recognize (precipitate) active $\mathrm{CO}$ in solution and bind to inactive enzyme subunits in immunoblots. The immunohistochemical controls show that the labeling is specific in tissue sections. The local intensity of immunohistochemical staining thus shows the relative distribution of $\mathrm{CO}$ molecules.

\section{Correlation of $\mathrm{CO}$ amount and activity}

Our immunohistochemical results (Figs. 8-11) show that regions of neural tissue rich in $\mathrm{CO}$ histochemical activity are also rich in $\mathrm{CO}$ immunohistochemical amount. This conclusion is general, since the results were similar in all regions examined in the 2 species and have been confirmed in other regions and other species (R. F. Hevner et al., unpublished observations). Our findings indicate that the local activity of $\mathrm{CO}$ is determined mainly by the local distribution of enzyme molecules rather than by modulation of enzyme turnover number.

\footnotetext{
Figure 11. Correlation of $\mathrm{CO}$ activity and amount distributions in the monkey hippocampus. Neighboring frozen sections (30 $\mu \mathrm{m})$ were cut perpendicular to the long axis of the hippocampus and stained with cresyl violet $(a)$, CO histochemistry $(b)$, or $\mathrm{CO}$ immunohistochemistry $(c)$. The section in $c$ was incubated with anti-CO at 1:4000, then processed with GaR-HRP and DAB. Note the correspondence between the histochemical and immunohistochemical labeling in stratum moleculare of CA1, stratum pyramidale of CA3, stratum radiatum of CA3, and especially in the dentate molecular and granule cell layers. The dentate molecular layer appears homogeneous in the Nissl stain but has higher levels of CO histochemical activity and immunohistochemical amount in its outer portion relative to its inner portion. $A L V$, alveus; $S O$, stratum oriens; $S P$, stratum pyramidale; $S L$, stratum lucidum; $S R$, stratum radiatum; $S M$, stratum moleculare; $M L$, molecular layer of dentate gyrus; $G C L$, granule cell layer.
} 
The correlation between the histochemical and the immunohistochemical distributions of $\mathrm{CO}$ could also be explained by postulating that the antibodies recognize only active $\mathrm{CO}$. However, the antibodies recognized isolated (enzymatically inactive) $\mathrm{CO}$ subunits in immunoblots (Fig. 6). Furthermore, the antibodies are polyclonal and probably recognize several epitopes. It is unlikely that any modifications of the enzyme affecting its turnover number would influence all or most of the epitopes.

Differences were seen between the histochemical and immunohistochemical patterns. Less contrast in staining intensity among different regions of a tissue section was present in immunohistochemistry than in histochemistry. The lower contrast can be partly attributed to the background staining always present in immunohistochemistry. Also, the signal : noise ratio of the immunohistochemistry may be less than that of the histochemistry if fewer $\mathrm{CO}$ molecules bind antibody than react histochemically. Another difference between the two methods was that cell bodies were sometimes more intensely labeled immunohistochemically than histochemically. For example, in the cerebellar cortex, somata in the molecular layer were stained immunohistochemically but not histochemically (Fig. 10). This cellular staining could be due to newly synthesized subunit IV, since this subunit is encoded in the nuclear genome (only subunits I-III are mitochondrially encoded) and presumably translated on ribosomes in the soma before incorporation into $\mathrm{mi}$ tochondria and active enzyme. Another possibility is that a cell body protein cross-reacts immunohistochemically, but this seems unlikely, since not all cell bodies were stained.

Finally, it is possible that local regulation of the turnover number of the enzyme could account for each of the histochemical/immunohistochemical differences. A role for turnover number regulation cannot be excluded but would probably be minor under normal conditions, given the close match found between $\mathrm{CO}$ amount and activity. Indeed, the differences between the histochemical and immunohistochemical patterns may not have been significant, considering that the two methods showed nearly identical patterns in complex tissues.

\section{Distribution of energy metabolic capacity in neural tissue}

$\mathrm{CO}$ is not the only indicator that the capacity for generating metabolic energy varies among neural tissue regions. Other energy metabolic enzymes show activity or amount distribution patterns similar to those of $\mathrm{CO}$. For example, succinate dehydrogenase (Killackey et al., 1976) and citrate synthase (Dietrich et al., 1981) have, like CO, higher activity levels in the barrel hollows of the mouse somatosensory cortex layer IV than in the septa or surrounding cortex. Also, the distribution of hexokinase (both immunohistochemical amount and histochemical activity) in the cerebellar cortex (Wilkin and Wilson, 1977) closely resembles that of $\mathrm{CO}$. The results of this study confirm that not only the activity of a metabolic enzyme but also the concentration of enzyme molecules can vary locally and confer different metabolic capacities on regions of neural tissue.

Our results, furthermore, suggest that the concentration of $\mathrm{CO}$ molecules varies among processes and segments of processes within individual neurons. Previous studies at the electron microscopic level have found that $\mathrm{CO}$ activity does vary among different segments of the same neuron. For example, dentate granule cells have high $\mathrm{CO}$ activity levels in their distal apical dendrites in the outer molecular layer but low levels in their proximal dendrites in the inner molecular layer (Kageyama and Wong-Riley, 1982). The outer molecular layer of the dentate gyrus is also rich in $\mathrm{CO}$ amount relative to the inner molecular layer (Fig. 11). This suggests that the dentate granule cell distal apical dendrites are enriched in $\mathrm{CO}$ molecules relative to proximal dendrites of the same neurons.

Similar arguments suggest that $\mathrm{CO}$ amount varies among processes and segments of individual neurons in the mouse somatosensory barrels and in the mouse cerebellum. In the barrels, $\mathrm{CO}$ activity is higher in dendrites in the hollows than in cell bodies in the septa (Wong-Riley and Welt, 1980). In the adult cerebellum, Purkinje cells have high $\mathrm{CO}$ activity in their dendrites relative to lower levels in their somata (Mjaatvedt and Wong-Riley, 1988). The pattern of CO immunohistochemistry matched that of $\mathrm{CO}$ histochemistry in both of these regions (Figs. 8, 10), suggesting again that the intracellular distribution of $\mathrm{CO}$ amount, like that of $\mathrm{CO}$ activity, might be nonhomogeneous. Verification of this will require $\mathrm{CO}$ immunocytochemistry at the electron microscopic level.

A nonhomogeneous distribution of $\mathrm{CO}$ molecules in individual neurons implies the existence of a mechanism for distributing $\mathrm{CO}$ molecules differentially among processes and their segments. The intracellular distribution of $\mathrm{CO}$ amount could be determined simply by the distribution of mitochondria, or mitochondria could be evenly distributed but contain different amounts of $\mathrm{CO}$. Histochemically, individual mitochondria do differ in their relative $\mathrm{CO}$ activity, and more reactive mitochondria usually are found in tissue regions that appear more reactive at the light microscopic level (reviewed in Wong-Riley, 1989).

Whatever the mechanisms may be for distributing $\mathrm{CO}$ (or other energy metabolic enzymes) within cells and tissue, we think that such mechanisms probably are coupled to encrgy demand and thus indirectly to neural functional activity.

\section{Regulation of energy metabolic capacity}

The capacity for generating metabolic energy, as demonstrated by $\mathrm{CO}$ histochemistry, not only is unevenly distributed but also can change in response to alterations in neural functional activity (reviewed in Wong-Riley, 1989). We recently found in the primate visual system that not just the activity but the amount of $\mathrm{CO}$ is regulated by neural functional activity. Monocular retinal impulse blockage with TTX causes CO activity as well as immunoreactivity to decline in LGN laminae and cortical columns corresponding to the TTX-injected eye (R. F. Hevner and M. T. T. Wong-Riley, unpublished observations). The results of our studies indicate that the quantity and distribution of $\mathrm{CO}$ in neural tissue probably are determined by the level and pattern, respectively, of functional activity.

The CO immunohistochemical method should serve as a useful complement to $\mathrm{CO}$ histochemistry in future studies of brain energy metabolism and functional anatomy. For example, the relation between $\mathrm{CO}$ and other molecules can be investigated by double-label immunohistochemistry. We have used this method to investigate the relation between GABA and $\mathrm{CO}$ in the cat brain (Luo et al., 1989). We have also applied this method in studies, currently in progress, of cultured cells and of developing animals.

\section{References}

Bradford, M. M. (1976) A rapid and sensitive method for the quantitation of microgram quantities of protein utilizing the principle of protein-dye binding. Anal. Biochem. 72: 248-254. 
Broger, C., K. Bill, and A. Azzi (1986) Affinity chromatography purification of cytochrome- $c$ oxidase from bovine heart mitochondria and other sources. Methods Enzymol. 126: 64-72.

Carroll, E. W., and M. T. T. Wong-Riley (1984) Quantitative light and electron microscopic analysis of cytochrome oxidase-rich zones in the striate cortex of the squirrel monkey. J. Comp. Neurol. 222: $1-17$.

Cohen, P. (1980a) Well-established systems of enzyme regulation by reversible phosphorylation. In Recently Discovered Systems of Enzyme Regulation by Reversible Phosphorylation, P. Cohen, ed., pp. 1-10, Elsevier/North-Holland, Amsterdam.

Cohen, P. (1980b) Protein phosphorylation and the co-ordinated control of intermediary metabolism. In Recently Discovered Systems of Enzyme Regulation by Reversible Phosphorylation, P. Cohen, ed., pp. 255-268, Elsevier/North-Holland, Amsterdam.

Dietrich, W. D., D. Durham, O. H. Lowry, and T. A. Woolsey (1981) Quantitative histochemical effects of whisker damage on single identified cortical barrels in the adult mouse. J. Neurosci. 1: 929-935.

Dion, A. S., and A. A. Pomenti (1983) Ammoniacal silver staining of proteins: Mechanism of glutaraldehyde enhancement. Anal. Biochem. 129: 490-496.

Dunaway, G. A., and T. P. Kasten (1988) Physiological implications of the alteration of 6-phosphofructo-1-kinase isozyme pools during brain development and aging. Brain Res. 456: 310-316.

Errede, B., M. D. Kamen, and Y. Hatefi (1978) Preparation and properties of complex IV (ferrocytochrome $c$ : oxygen oxidoreductase EC 1.9.3.1). Methods Enzymol. 53: 40-47.

Hartzell, C. R., H. Beinert, B. F. van Gelder, and T. E. King (1978) Preparation of cytochrome oxidase from beef heart. Methods Enzymol. 53: 54-66.

Hartzell, C. R., H. Beinert, G. T. Babcock, S. I. Chan, G. Palmer, and R. A. Scott (1988) Heterogeneity in an isolated membrane protein. FEBS Lett. 236: $1-4$.

Hatefi, Y. (1978) Preparation and properties of dihydroubiquinone: cytochrome $c$ oxidoreductase (complex III). Methods Enzymol. 53: $35-40$.

Hendrickson, A. E., and J. R. Wilson (1979) A difference in $\left[{ }^{14} \mathrm{C}\right]$ deoxyglucose autoradiographic patterns in striate cortex between Macaca and Saimiri monkeys following monocular stimulation. Brain Res. 170: 353-358.

Hevner, R. F., and M. T. T. Wong-Riley (1987) Purification of bovine brain cytochrome oxidase from synaptosomal and non-synaptosomal mitochondria. Soc. Ncurosci. Abstr. 13: 647.

Horton, J. C. (1984) Cytochrome oxidase patches: A new cytoarchitectonic feature of monkey visual cortex. Phil. Trans. R. Soc. Lond. B 304: 199-253.

Horton, J. C., and D. H. Hubel (1981) Regular patchy distribution of cytochrome oxidase staining in primary visual cortex of macaque monkey. Nature 292: 762-764.

Hurn, B. A. L., and S. M. Chantler (1980) Production of reagent antibodies. Methods Enzymol. 70: 104-142.

Ip, M. M., P. Y. Chee, and R. W. Swick (1974) Turnover of hepatic mitochondrial ornithine aminotransferase and cytochrome oxidase using $\left[{ }^{14} \mathrm{C}\right]$ carbonate as tracer. Biochim. Biophys. Acta 354: 29-38.

Jacobs, E. E., and D. R. Sanadi (1960) The reversible removal of cytochrome $c$ from mitochondria. J. Biol. Chem. 235: 531-534.

Jacobs, E. E., E. C. Andrews, W. Cunningham, and F. L. Crane (1966a) Membraneous cytochrome oxidase: Purification, properties, and reaction characteristics. Biochem. Biophys. Res. Commun. 25: 87-95.

Jacobs, E. E., F. H. Kirkpatrick, Jr., E. C. Andrews, W. Cunningham, and F. L. Crane (1966b) Lipid-free soluble cytochrome oxidase: Purification, properties, and reaction characteristics. Biochem. Biophys. Res. Comm. 25: 96-104.

Jarausch, J., and B. Kadenbach (1982) Tissue-specificity overrides species-specificity in cytoplasmic cytochrome $c$ oxidase polypeptides. Hoppe Seylers Z. Physiol. Chem. 363: 1133-1140.

Johnson, D. A., J. W. Gautsch, J. R. Sportsman, and J. H. Elder (1984) Improved technique utilizing nonfat dry milk for analysis of proteins and nucleic acids transferred to nitrocellulose. Gene Anal. Tech. I: 3-8.

Johnstone, A., and R. Thorpe (1982) Immunochemistry in Practice, Blackwell, Oxford.

Kadenbach, B., J. Jarausch, R. Hartmann, and P. Merle (1983) Separation of mammalian cytochrome $c$ oxidase into 13 polypeptides by a sodium dodecyl sulfate-gel electrophoretic procedure. Anal. Biochem. 129: 517-521.

Kadenbach, B., A. Stroh, M. Ungibauer, L. Kuhn-Nentwig, U. Buge, and J. Jarausch (1986) Isozymes of cytochrome $c$ oxidase: Characterization and isolation from different tissues. Methods Enzymol. 126: $32-45$.

Kadenbach, B., L. Kuhn-Nentwig, and U. Buge (1987) Evolution of a regulatory enzyme: Cytochrome-c oxidase (complex IV). Curr. Topics Bioenerg. 15: 113-161.

Kageyama, G. H., and M. T. T. Wong-Riley (1982) Histochemical localization of cytochrome oxidase in the hippocampus: Correlation with specific neuronal types and afferent pathways. Neuroscience 7 : 2337-2361.

Kennedy, C., M. H. Des Rosiers, O. Sakurada, M. Shinohara, M. Reivich, J. W. Jehle, and L. Sokoloff (1976) Metabolic mapping of the primary visual system of the monkey by means of the autoradiographic $\left[{ }^{14} \mathrm{C}\right]$ deoxyglucose technique. Proc. Natl. Acad. Sci. USA 73. $4230-4234$.

Killackey, H. P., G. Belford, R. Ryugo, and D. K. Ryugo (1976) Anomalous organization of thalamocortical projections consequent to vibrissae removal in the newborn rat and mouse. Brain Res. 104: 309315.

Krnjevic, K. (1975) Coupling of neuronal metabolism and electrical activity. In Brain Work: The Coupling of Function, Metabolism, and Blood Flow in the Brain, D. H. Ingvar and N. A. Lassen, eds., pp. 65-78, Academic, New York.

Kuhn-Nentwig, L., and B. Kadenbach (1985) Isolation and properties of cytochrome $c$ oxidase from rat liver and quantification of immunological differences between isozymes from various rat tissues with subunit-specific antisera. Eur. J. Biochem. 149: 147-158.

Lai, J. C. K., and J. B. Clark (1979) Preparation of synaptic and nonsynaptic mitochondria from mammalian brain. Methods Enzymol. 55: 51-60.

Livingstone, M. S., and D. H. Hubel (1984) Anatomy and physiology of a color system in the primate visual cortex. J. Neurosci. 4: 309356.

Luo, X. G., R. F. Hevner, and M. T. T. Wong-Riley (1989) Double labeling of cytochrome oxidase and gamma aminobutyric acid in central nervous system neurons of adult cats. J. Neurosci. Meth. (in press).

Maker, H. S., G. M. Lehrer, S. Weissbarth, and M. B. Bornstein (1972) Changes in LDH isoenzymes of brain developing in situ and in vitro. Brain Res. 44: 189-196.

Meinecke, L., and G. Buse (1985) Studies on cytochrome $c$ oxidase, XII. Isolation and primary structure of polypeptide VIb from bovine heart. Biol. Chem. Hoppe Seyler 366: 687-694.

Merle, P., and B. Kadenbach (1980) The subunit composition of mammalian cytochrome $c$ oxidase. Eur. J. Biochem. 105: 499-507.

Merle, P., J. Jarausch, M. Trapp, R. Scherka, and B. Kadenbach (1981) Immunological and chemical characterization of rat liver cytochrome $c$ oxidase. Biochim. Biophys. Acta 669: 222-230.

Mjaatvedt, A. E., and M. T. T. Wong-Riley (1988) Relationship between synaptogenesis and cytochrome oxidase activity in Purkinje cells of the developing rat cerebellum. J. Comp. Neurol. 277: 155182.

Nakagawa, M., and A. F. Miranda (1987) A monoclonal antibody against cytochrome $c$ oxidase distinguishes cardiac and skclctal muscle mitochondria. Exp. Cell Res. 168: 44-52.

Nicholls, P., C. E. Cooper, B. Leece, J. A. Freedman, and S. H. P. Chan (1988) Antibodies as probes of cytochrome oxidase structure and function. In Oxidases and Related Redox Systems, T. E. King, H. S. Mason, and M. Morrison, eds., pp. 637-651, Liss, New York.

Ozawa, T., M. Tanaka, and T. Wakabayashi (1982) Crystallization of mitochondrial cytochrome oxidase. Proc. Natl. Acad. Sci. USA 79: 7175-7179.

Read, S. M., and D. H. Northcote (1981) Minimization of variation in the response to different proteins of the Coomassie blue $\mathrm{G}$ dyebinding assay for protein. Anal. Biochem. 116: 53-64.

Rendon, A., and A. Masmoudi (1985) Purification of non-synaptic and synaptic mitochondria and plasma membranes from rat brain by a rapid Percoll gradient procedure. J. Neurosci. Methods 14: 41-51.

Robinson, N. C., and R. A. Capaldi (1977) Interaction of detergents with cytochrome $c$ oxidase. Biochemistry 16: 375-381.

Saraste, M. (1983) How complex is a respiratory complex? Trends Biochem. Sci. 8: 139-142. 
Schimke, R. T., and D. Doyle (1970) Control of enzyme levels in animal tissues. Annu. Rev. Biochem. 39: 929-976.

Sokoloff, L. (1984) Metabolic Probes of Central Nervous System Activity in Experimental Animals and Man, Sinauer, Sunderland, Mass.

Surolia, A., D. Pain, and M. I. Khan (1982) Protein A: Nature's universal anti-antibody. Trends Biochem. Sci. 7: 74-76.

Swanson, L. W. (1982) Normal hippocampal circuitry: Anatomy. Neurosci. Res. Prog. Bull. 20: 624-634.

Tootell, R. B. H., M. S. Silverman, S. L. Hamilton, R. L. De Valois, and E. Switkes (1988) Functional anatomy of macaque striate cortex. III. Color. J. Neurosci. 8: 1569-1593.

Towbin, H., T. Staehelin, and J. Gordon (1979) Electrophoretic transfer of proteins from polyacrylamide gels to nitrocellulose sheets: Procedure and some applications. Proc. Natl. Acad. Sci. USA 76: 43504354.

Vanneste, W. H. (1966) Molecular proportion of the fixed cytochrome components of the respiratory chain of Keilin-Hartree particles and beef heart mitochondria. Biochim. Biophys. Acta 113: 175-178.

Vik, S. B., and R. A. Capaldi (1980) Conditions for optimal electron transfer activity of cytochrome $c$ oxidase isolated from beef heart mitochondria. Biochem. Biophys. Res. Commun. 94: 348-354.
Wharton, D. C., and A. Tzagoloff (1967) Cytochrome oxidase from beef heart mitochondria. Methods Enzymol. 10: 245-250.

Wilkin, G. P., and J. E. Wilson (1977) Localization of hexokinase in neural tissue: Light microscopic studies with immunofluorescence and histochemical procedures. J. Neurochem. 29: 1039-1051.

Wong-Riley, M. (1979) Changes in the visual system of monocularly sutured or enucleated cats demonstrable with cytochrome oxidase histochemistry. Brain Res. 171: 11-28.

Wong-Riley, M. T. T. (1989) Cytochrome oxidase: An endogenous metabolic marker for neuronal activity. Trends Neurosci. 12:94-101.

Wong-Riley, M. T. T., and C. Welt (1980) Histochemical changes in cytochrome oxidase of cortical barrels after vibrissal removal in neonatal and adult mice. Proc. Natl. Acad. Sci. USA 77: 2333-2337.

Woolsey, T. A., and H. van der Loos (1970) The structural organization of layer IV in the somatosensory region (SI) of mouse cerebral cortex. The description of a cortical field composed of discrete cytoarchitectonic units. Brain Res. 17: 205-242.

Wray, W., T. Boulikas, V. P. Wray, and R. Hancock (1981) Silver staining of proteins in polyacrylamide gels. Anal. Biochem. 118: 197203. 